\title{
Metal-smithy, Bead-making, Gemstones, Jeweller's Weight, Trade-permits, Tax-stamps: Indus Script's Semasiography Partly Decoded
}

\section{Abstract}

This paper claims to have partly decoded the Indus script. It not only explains how the brief formulaic inscriptions found on seals and tablets helped in taxation and trade control, by recording taxed commodity-types, licensed commercial activities, tax-rates, mode of tax-payment, license-issuing entities etc., but also decisively identifies several semasiograms signifying metal-smithy, lapidaryworks, related metrology and taxation. It shows how the sign (b) resembling a "blowpipe inside a crucible", repeatedly occurs in inscribed seals/tablets discovered from workshops of metal-workers, goldsmiths and bead-makers, and directly occurs on certain inscribed gold and copper implements.

Crucibles and blowpipes being ancient smelting tools, their ideograms

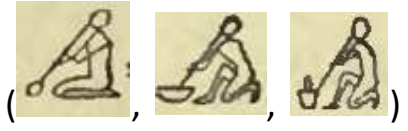
denoted gold-smithy in Egyptian hieroglyphs too. Moreover, certain Indo-Aryan and Dravidian words for metal-smith directly translates to "blowpipe-blower". Thus archaeological, script-internal and linguistic evidence confirm that sign 10 signified precious metals and metal-smithy in different contexts. Similarly, fish-like signs ( $\hat{x}, \hat{\AA}$, etc.), which repeatedly occur in inscriptions discovered from bead-makers' and jewelers' workshops across Indus settlements, arguably signified meanings associated with gemstones, bead-making and related metrological standards. Interestingly, in ProtoDravidian, "mīn" means fish, shining, bright, and gemstone. Moreover, Indus valley's eye-patterned gemstone beads were famous as "fish-eye beads" in Mesopotamia. The gemstone related fish-signs sometimes co-occur with (f), possibly because, the bead-makers and goldsmiths, who physically shared same workshops, were part of related trade license and taxation mechanisms. This paper also claims that the frequent terminal signs symbolized different volumetric ( $)$ and weight-based ( \$大,

metrological units used in revenue collection and thus metonymically signified certain tax categories. Specifically, the terminal arrow-like sign $\uparrow$, which mostly co-occurs with gemstone and gold-smithy related semasiograms, arguably symbolized a goldsmith's balance, and metonymically signified tax-payments and trade-permits associated with precious commodities. Since ancient assay balances generally used arrow-like pointers for precise weight measurement (a comparable balance is discovered from Harappa), Indic words for assay balance (eșaṇī, nārācī) are often etymologically rooted to arrow-words. This study claims that sign (allograph $V$ ), symbolized the abrus precatorious seeds, the traditional Indian jeweller's weight, and metonymically signified goldsmith's weight system and treasury. Many other related conjectures of this study significantly advance our understanding of Indus script. 


\section{Introduction}

Indus valley inscriptions (henceforth Indus-Inscriptions), are one of the most enigmatic aspects of Indus valley civilization (IVC). They are embodied in nearly 4000 inscribed objects, mostly comprising inscribed seals, sealings (seal-impressions), tablets (incised, bas-relief and copper-made), ivory/bone rods and pottery vessels (see Fig. 1), excavated from various locations IVC that spanned around 800,000 square kilometres and had over 1500 settlements at its peak (c. 2600-1900 BCE) (Kenoyer, 2010). A few Indus seals were also found from parts of ancient Near East, with whom IVC had thriving trade relationships. Decoding the messages of Indus-Inscriptions would make a major impact on our understanding of the ancient culture prevalent in the Indo-Pakistani subcontinent. However, the facts that most of the Indus-Inscriptions are written very briefly (around $74 \%$ of the distinct inscription-lines contain only 1 to 5 signs), and that the script(s) used in the inscriptions is/are completely unknown have made the decipherment very difficult.

Ever since the first publication of an inscribed Indus seal in 1875, Indus script has received several theories and more than 60 claimed decipherments (Wells, 2011). Most of the Indus scholars agree on certain structural aspects of the script, including: the direction of writing used in the inscriptions (predominantly right-to-left); homologous usage patterns of certain initial and terminal signs present in the inscriptions; existence of certain numerical notations; and certain generally adopted inscription-segmentation techniques (Mahadevan, 1986). Although the extensive scholarly researches have provided several significant insights, none of the claimed decipherments have achieved appreciable consensus. The dissensus ranges from opinions that Indus inscriptions were written logo-syllabically (Parpola A, 1994: 85; Wells, 2015: 32, 85) or logographically (Mahadevan, 1986, Ansumali-Mukhopadhyay 2019) to the idea that "Indus inscriptions did not encode speech" at all (Farmer, Sproat, and Witzel, 2004). The underlying language of the script is argued to be Dravidian by some scholars (Mahadevan, 2014; Parpola A., 1994: 274), and linked to Indo-Aryan languages by some others (Rao, 1982). The meanings of the inscriptions and the functionality of most of the signs are also fiercely debated. For example, the frequent fish-like sign $\&$ is classified as a syllabic sign by Wells (2015:7), an attributive-lexeme by Mahadevan (1986:21), and a metrological unit by Bonta (2010: 57). Parpola (1994:179-185,279-283) suggests that $\&$ might have represented the Dravidian word "mīn" which meant "fish", "star" and "to shine or glitter" and was part of certain theophoric astral names used in IVC. Similarly $\mathcal{U}$, the most frequent sign of Indus script, is considered as a Dravidian "pronominal masculine singular suffix" by Mahadevan $(2014: 10,17)$, that sometimes conveyed an ideographic meaning of a "sacrificial vessel with food offerings". Wells (2015: 88) considered $\amalg$ as a terminal marker that might have been a verbal ending with the sound value "ay", also meaning "cow" and "mother" in proto-Dravidian. But to Bonta (2010:76-82) $\mathcal{U}$ is a predicate or root, expressing the meanings "be" or "belong to", that could have been a general predicate-marker. These completely contradictory interpretations about signs \& and representatively reflect the extent of controversies associated with the other Indus signs. 
Figure 1. Schematic representations of Indus inscriptions found on different type of media.

a) Inscribed stamp seal of Mohenjo-daro; b) Inscribed sealing of Harappa; c) Obverse and reverse sides of three inscribed miniature-tablets of Harappa; d) Inscribed copper-tablet of Mohenjo-daro; e) Inscribed ivory-stick of Mohenjo-daro f) Inscribed pottery-shards and vessels

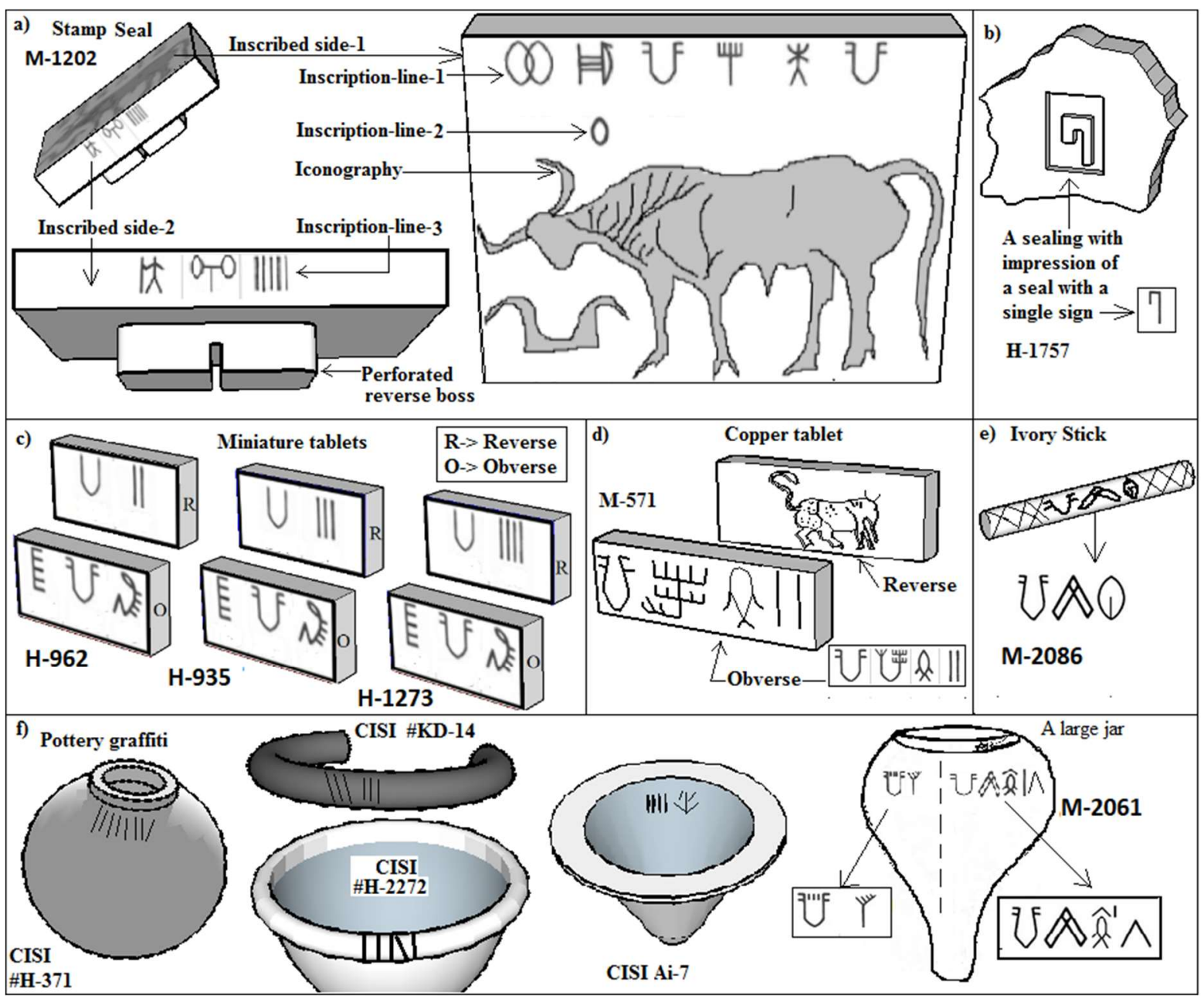

\section{How this paper approaches the perennial puzzle of Indus-Inscriptions:}

Decipherment of all the undeciphered scripts of the world has depended on certain known clues to unravel the unknown. For example, Egyptian Hieroglyphic, Old Persian Cuneiform, and Akkadian cuneiform were deciphered based on multilingual scripts, some inklings about the scripts' underlying languages and known proper names, whereas Linear B was deciphered based on positional-statistical analysis of the inscriptions, their contextualization and known Greek toponyms. This study believes that the known factors in case of Indus-Inscriptions are the iconicity of the Indus signs, their positional-statistical features, and the archaeological contexts they were found in. It draws upon the exhaustive structural analysis of Indus-Inscriptions done in Ansumali-Mukhopadhyay (2019), which 
established that the Indus inscriptions were predominantly written using logograms/semasiograms, and that the majority of the seal and tablet inscriptions neither used phonograms nor applied rebus principle. Ansumali-Mukhopadhyay (2019) conclusively established that: i) the co-occurrence restriction patterns maintained by functionally homologous Indus signs were provably semantic cooccurrence restrictions not phonological co-occurrence restrictions; ii) these signs were used as semasiograms not phonograms; and iii) the rigid formulaic positional preferences of many Indus signs would allow a grievously limited sound combinations, which could not have phonetically encoded speech of any natural language. Now, if Indus-Inscriptions are predominantly semasiographic, then their signs would be quite ill-suited to encode or spell out proper nouns such as anthroponyms or toponyms. Moreover, discovery of most of the frequent Indus signs in seals across Indus settlements (see examples in Fig. 11), indicates that most of the semasiograms did not represent toponyms. Besides, the pictographic graphemes of Indus signs often seem to have a direct relation to their context of usage. For example, certain uncommon round baked-clay pendants with holes in centre, were discovered from Kanmer, Gujarat. Each pendant had a seal-impression with the sign-sequence 贞 $\mid$ in obverse, and a few obscure signs scribbled in reverse. Toshiki Osada conjectures that these pendants possibly "served as a passport for those traveling between different regions" (https://www.harappa.com/blog/ancient-indus-passports). Now, since Kanmer was a highly fortified rural site situated near an agate quarry, extensively used for bead-making, this Indus semasiogram depicting a walking person with a mining-rake like implement attached at his waist, possibly represented mining workers, who needed to show a gate-pass for entering the fortified area. This inference closely matches Osada's above-mentioned inference/hypothesis about passport, indicating that contextualization of Indus-Inscriptions and its signs might hold the very clue to decipherment. Encouraged by this insight, this study tries to analyse the archaeological contexts of Indus-Inscriptions by consulting several excavation reports and scholarly analyses, and proposes that the inscribed seals and tablets were used for exerting various administrative controls in commercial contexts. For example, when a trader had to bring in his merchandise inside a fortified settlement of Indus valley to sell his goods inside the regulated market area, his commodities were possibly checked, weighed and measured at the city gates, and he possibly had to pay specific types of taxes to certain controlling organizations of that fortified settlement, and the payment of that tax was recorded on the soft-clay tags attached to his merchandise packages. Archaeological evidence of Indus sealings with impression of packing material on their back-sides, and concentration of seals and weights near the fortified city-gates (Kenoyer, 2010) supports this conjecture. Similarly, the owners of the lapidary, metal-smithy and shell-bangle-making workshops that operated inside the Indus cities must have procured certain business-permits for working on specific commodities and must have paid additional sell taxes. The bas-relief and incised tablets often found near such workshops (Mackay, 1943; Kenoyer 2010), might have functioned as trade-permits and commercial licences issued to the owners of such workshops, whereas tax-collectors appointed by the city's trade-controlling organizations or merchant-guilds possibly monitored such workshops, collected the needed taxes, and endorsed the commodities with "tax-paid" type stamps using their specific seals. All these conjectures are substantiated using archaeological evidence in subsequent sections of this paper. Now, having narrowed down the semantic scope of the inscriptions, this study contextualizes them further, to ascertain which Indus signs were occurring in which specific archaeological contexts and whether the iconicity of those signs matches those archaeological contexts. This approach has led to the revelation that sign $(f)$ and its allographs $(U, \Delta)$, which visually resemble a pot with a stick/pipe inside, symbolize a crucible with a blowpipe, and occur repeatedly in archaeological contexts of metal-workers' workshops, goldsmiths' shops and bead-makers' shops, had signified 
precious metals, gold-smithy and metal-smithy. Interestingly, Telugu, a Dravidian language, "kommu" means both horn-blower and goldsmith, and "nāḍindhamuḍu" means goldsmith as "nāḍi" means pipe, tube, and blowpipe (Brown, 1903). Similarly, in Sanskrit "nāḍindhama" means goldsmith (Haughton, 1987). Thus, for sign (d) iconicity, linguistic evidence, and archaeological evidence match completely, producing an unassailable proof of decipherment.

Using similar methodology, this study proves that the fish-signs were semantically related to bead-making, jewellery, jeweller's weights, related trade-permits and taxed-commodity types. This study also claims that the arrow-sign $\uparrow$, a frequent sign that occurs in terminal positions of IndusInscriptions, symbolized the goldsmith's balance, and metonymically signified tax-payments and commercial licences of commodities like precious stones, precious metals, beads, shell bangles and other precious goods that had to be measured with assay balances and small weights. Ancient Indian languages like Sanskrit, use more than one words that mean both arrow (eșaṇ, nārāc) and assay balance (eșaṇī, nārācī) (Haughton, 1987), possibly because the goldsmith's balance used such arrowlike pointers to minutely indicate equality of both scale-pans while measuring special metals and stones (Fig. 2d). Such weighing scales are also discovered from Indus settlements (Kenoyer, 2010). Based on these primary and direct decipherments, this study identifies several other signs which must have signified different meanings related to metalwork, jewellery-work, bead-making, and treasury. Some of the conjectures about signs depend on the script-internal evidence comprising the signs' iconicity and positional-statistical features, and also the signs' shared archaeological and inscriptional contexts with the directly deciphered signs. For example, the anthropomorphic signs

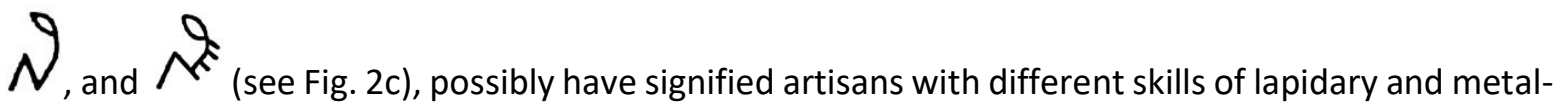
smithy related works, as they visually resemble a person in a sitting position, and repeatedly occur

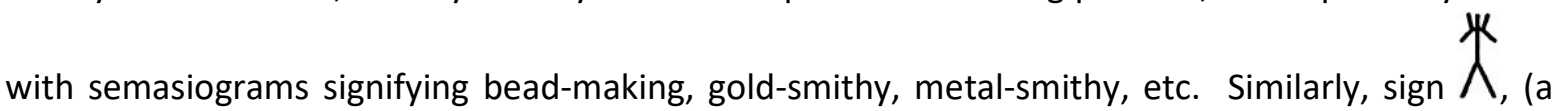
man-with-a-pot-on-his-head) possibly meant a smelter - this conjecture depends on the sign's iconicity, inscriptional context and archaeological context (see Section-X). These primary and secondary decipherments help us understand the overall meanings of several Indus inscriptions. For example, when a bas-relief tablet of Harappa (H-1792) contains the inscription $\lambda \curvearrowright$, we can safely infer that the tablet's owner possibly needed it as a permit to run a metal-smithy related workshop and to employ artisans of related skills. Similarly, we can understand the meanings of

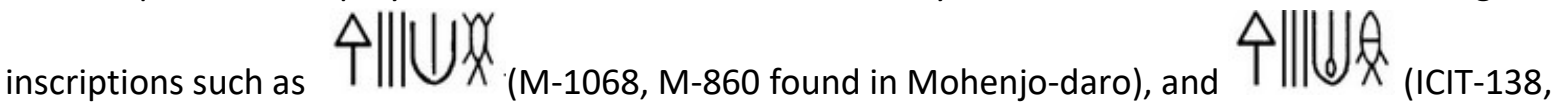
Dholavira). These inscriptions, when impressed on a sealing or tag possibly meant that the sealing is endorsing the contents of precious beads, jewellery and precious metal type of artefacts in a container, for which the specified taxes were paid. Alternatively, the owner of the seal could also be using it as a commercial permit for manufacturing and trading such commodities. Another alternative use of these tablets could have been that, the authorized tax-collectors owned them to specify which kind of taxes they were supposed to collect! Considering that the owner of a jewellery workshop would need to execute both lapidary work and metal-smithy to make ornaments, he/she would thus need to procure trade permits for both activities, paying the necessary license fees/taxes for both. Since many Indus-Inscriptions record trade permits and tax-payment certificates, the commodities and/or activities which are commercially related to each other, are supposed to be represented with their semasiograms in the same inscriptions. This is the reason that the semasiograms related to 
lapidary-work often co-occurs with the semasiograms related to gold-smithy, in the same inscription. This paper proposes many such decipherments that are substantiated by archaeological, linguistic, historical and script-internal evidences.

\section{Materials and methods}

\subsection{Materials}

This study uses the intricately compiled Indus script corpus created by Bryan Wells (henceforth ICIT) and maintained and enhanced by Andreas Fuls (Wells, Bryan, and Fuls, Andreas: Interactive Concordance of Indus Texts (ICIT): An Online Database of Indus Inscriptions and Iconography. Berlin, last modified 29.11.2020, https://www.indus.epigraphica.de, last accessed February 2021). It also uses the excellent photographic corpora (henceforth CISI) created by Dr. Asko Parpola and his colleagues, (Joshi \& Parpola A, 1987; Shah \& Parpola A, 1991; Parpola A, Pande \& Koskikallio, 2010) to visualize the inscribed objects. This study has occasionally referred to the Indus script corpus compiled by Iravatham Mahadevan in 1977 (henceforth M77) to refer to some of his interpretations about certain Indus signs and their allographs. Other than these, this study has used several reports of archaeological excavations, their analyses, several texts and documents of ancient Mesopotamia, ancient Persia, and also various historical and linguistic documents of ancient India, as cited in the bibliography.

\subsection{Methods}

Methodologically, this study differs from most of the existing research on Indus-Inscriptions on the following counts:

i) It does not try to read Indus-Inscriptions phonologically or using rebus principle, but depends on the proofs given by Ansumali-Mukhopadhyay (2019) about the predominantly semasiographic nature of Indus-Inscriptions.

ii) It tries to contextualize Indus-Inscriptions through archaeological evidence and finds out that the inscribed seals and tablets were mostly used in the context of taxation and trade control.

iii) It tries to find what kind of information would be needed to record through the inscriptions, and conjectures that information about commodity-types, modes of taxation, rates of taxation, types of the tax-receiving entities, and purposes of paying the tax, are encoded in different segments of the brief inscriptions. It also identifies precise set(s) of functionally homologous semasiograms recording specific type(s) of the above-mentioned information.

iv) It tries to contextualize certain sets of inscriptions which were found together in specific archaeological contexts and analyses how individual signs of those inscriptions conveyed meanings relevant to such archaeological contexts. Towards this end, this study not only uses raw excavation data, and script-internal evidences, but also depends on various ancient Indic texts, and ancient trade related documents of ancient Near East, to find relevant historical and linguistic proofs to make its conjectures.

v) None of the claims made in this study tries to link Indus script to a specific language. However, as discussed below, certain symbolisms used in the Indus semasiograms have used considerable amount of metonymy and in some cases, they arguably have used homonymy too. Thus, even though I do not assign a particular linguistic word for any semasiogram deciphered in this study, I argue that the graphemes chosen could have originated not only 
from the abstract concepts related to those semasiograms, but also from the actual linguistic words used to denote such objects.

\section{Results and Discussion:}

This study's claim of partial decipherment of Indus-Inscriptions rests on five pillars:

Pillar-1: Understanding the semasiographic nature of Indus-Inscriptions (Section-3.1):

Building on the structural and contextual analyses done in Ansumali-Mukhopadhyay (2019), this study recognizes the semasiographic nature of Indus-Inscriptions, and the existence of certain functional classes of Indus signs. Thus, unlike many of the existing studies that try to read the IndusInscriptions in a logo-syllabic way, using rebus principle, (e.g. Parpola, 1994; Wells 2015), this study treats most of the Indus signs as semantic units. The studies that treat Indus script as a logo-syllabic script, generally try to find names of people and places spelled through the signs of Indus-Inscriptions (e.g. Wells, 2015:50-53; Parpola, 1994). Contrastingly, this article argues that the semasiographically written inscriptions were ill-suited for encoding anthroponyms and toponyms in a spelled manner. This study analyses Indus-inscriptions based on the archaeological contexts of their discovery, and tries to find the semantic relationships between the signs present in an inscription, with that inscription's archaeological context.

Pillar-2: Decisive decipherment of a related group of Indus signs (Section-3.2): This study deciphers

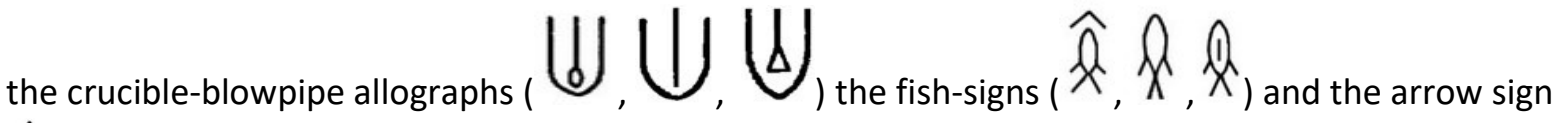
$\uparrow$, based on:

a) their shared archaeological contexts

b) their iconicity

c) ancient symbolisms related to their iconicity

d) linguistic words used in both the ancient Indo-Pakistani subcontinent and ancient Near East, that are directly related to the signs' iconicity and associated symbolisms.

Based on these direct decipherments, this study interprets many other signs, which not only co-occur with the deciphered signs in the same inscriptions sharing their archaeological contexts, but also are graphically similar to the deciphered signs, thus sharing their associated iconicity and symbolism. Please see Fig. $X$ for a list of such interpreted signs.

Pillar-3: Explanation of the general semantic scope of Indus-Inscriptions (Section-3.3):

This study explains the general semantic model used in Indus-Inscriptions.

Analysing the general archaeological contexts shared by most of the inscriptions, the typology of the inscribed objects, the formulaic structure of the inscriptions, and their 
geographic distribution, this study argues that Indus-Inscriptions were mostly used for the following purposes:

a) Imposing taxation.

b) Recording tax payments on merchandise moving between different regulated market areas of Indus settlements.

c) Issuing licenses or permits to people practising specific commercial activities: for example, permits for manufacturing and selling copper tools inside regulated market areas.

d) Issuing gate-passes for artisans and workers to allow them to enter or exit fortified regulated economic zones.

e) Keeping certain metrological records - especially the inscriptions incised on pottery artefacts arguably recorded capacities of those vessels, amounts of their contents, and sometimes the types and purposes of their contents. For example, a sealed vessel might contain some specific commodity used for paying taxes in the barter-based system, which might be indicated by the inscription incised on that vessel (e.g. M-2061).

\section{Pillar-4: Matching functionally homologous Indus signs with specific types of information recorded in Indus-Inscriptions (Section-3.4):}

Building on Ansumali-Mukhopadhyay's (2019) structural study, where Indus signs with similar positional-statistical and graphemic features are clustered into separated functional categories, this study explores what kinds of information were conveyed by such categories.

It provides a strong proof that the frequently terminal signs such as

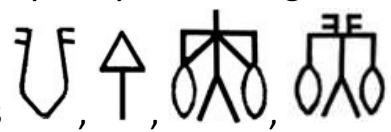
etc. (the Phrase-Final-Type-1 signs per Ansumali-Mukhopadhyay) were symbols of different metrological units (general volumetric unit, general weight-based unit, and goldsmith's weight standard used to weigh precious objects), and thus metonymically symbolized broad tax-categories based on the metrological mode of tax payment. It also conjectures that the

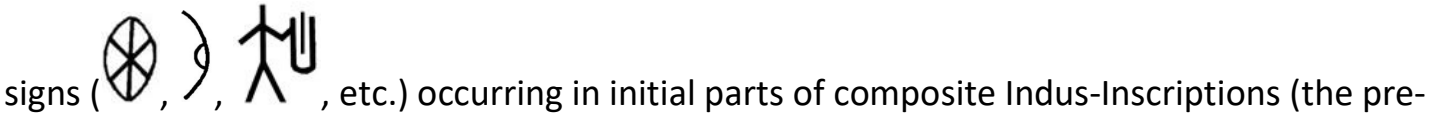
connective lexemes described in Ansumali-Mukhopadhyay (2019)) possibly signified the taxreceiving entities, purpose of tax payment etc (for example tax paid for maritime trade permit, tax paid to a metal-smithy guild, etc.). It further argues that the general semasiographs present in the inscriptions, which did not have rigid initial or terminal positional preferences, recorded the broad commodity-types and commercial activities for which taxes were paid and trade licenses were issued. Thus, this study provides an overall understanding of the semantic scope and mechanism of meaning conveyance used in the script.

\section{Pillar-5: Proposal of a new methodology used for Indus script decipherment (Section-3.5):}

This study offers a new method to be adopted in Indus script decipherment. It proposes that if we can find a sure archaeological context for a group of inscriptions found in the inscribed objects present in that specific context, we can have a good chance of deciphering certain semasiographs present in those inscriptions if their iconicity, their relationships to other such semasiographs of the script, their archaeological context, and the ancient symbolism associated with their iconicity can be reasonably matched. In many 
instances, the ancient linguistic words used for the concept signified by an Indus semasiogram, have a direct etymological relationship with the iconicity used in that semasiogram, that further confirms the decipherment. As discussed below, this article finds such layers of interlocking evidence for the decipherment of signs 2. 4.9

etc. This is a paradigm shift from the existing methodologies used in decipherment efforts, where the inscriptions are analysed without considering their archaeological contexts, and speculative assignments of sounds to Indus signs are attempted to read the semasiographic inscriptions phonologically, often using rebus principle.

\subsection{Structural aspects of Indus inscriptions}

As established in Ansumali-Mukhopadhyay (2019), among the Indus inscriptions excavated so far, the majority (if not all) are semasiographically constructed semantically complete phrases, which maintain quite formulaic phrase-structures. Almost all Indus signs function as semasiograms, some of which are general information-carrying semasiograms (possibly common nouns related to traded commodities and commercial activities) that appear in various positions of the inscriptions. Some other Indus signs belong to specific functional classes (see Fig. 2, adapted from Ansumali-Mukhopadhyay, 2019) and occur in more specific positions in the inscriptions' phrase-structures. Contrasted with the terms logographic and logograms used in Ansumali-Mukhopadhyay (2019), this paper prefers semasiographic and semasiograms, from this realization that it is not always possible to prove whether the Indus signs owed their iconicity to abstract concepts or actual linguistic words.

Figure 2. Representative examples of typical usage patterns of Indus sign-classes:

(a) Phrase-final and Pre-phrase-final signs; (b) Connective-morphemes and Pre-connective lexeme signs; (c) Metrological and Numerical signs; (d) CROP signs; and (e) Encapsulated signs. 


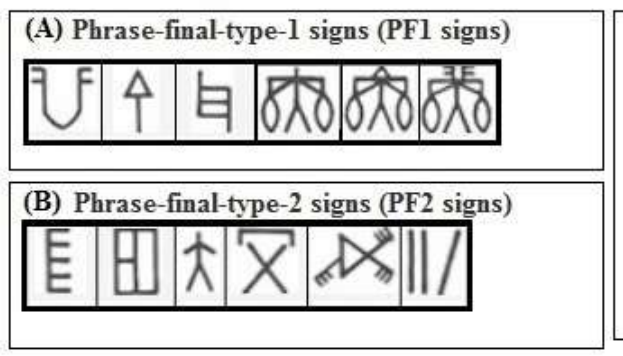

(E) Pre-Phrase-final signs (PPF signs)

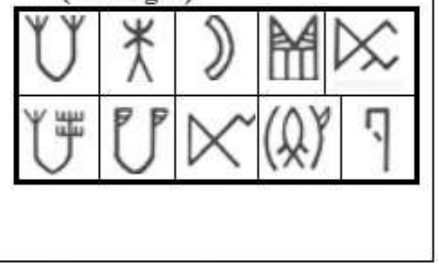

(F) Pre-Connective lexeme signs (PCL signs)

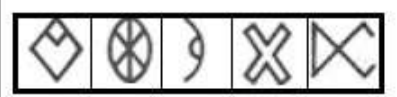

(C) Connective-morpheme signs (CM signs)

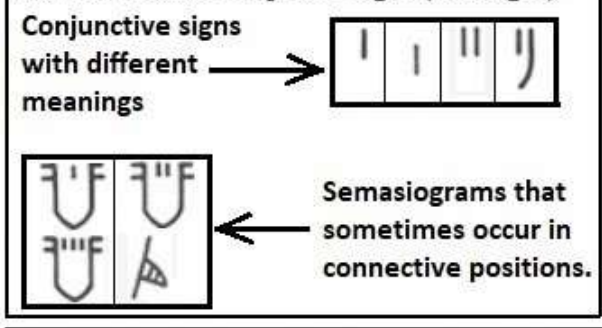

(D) Numerical/quantifier signs (NUM signs)
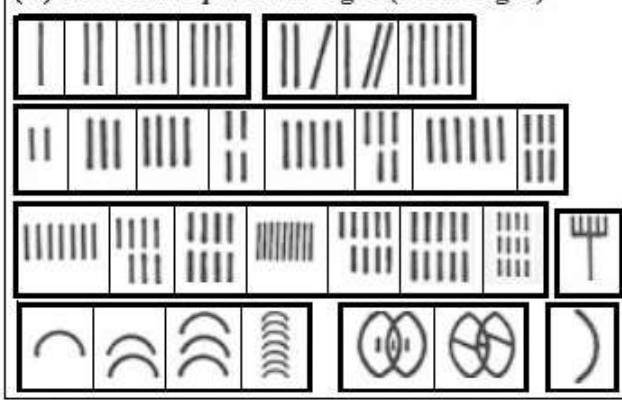

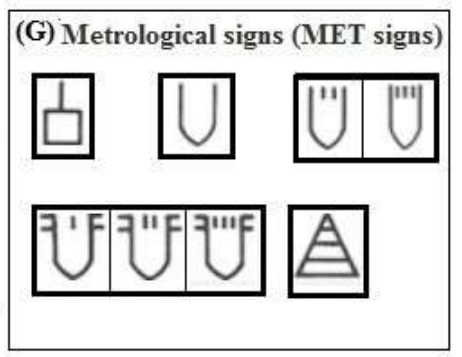

(H)

Phytomorphic signs

CROP-like signs (CROP)

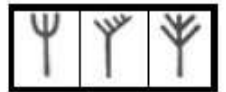

(I) Encapsulated signs (ENC signs)

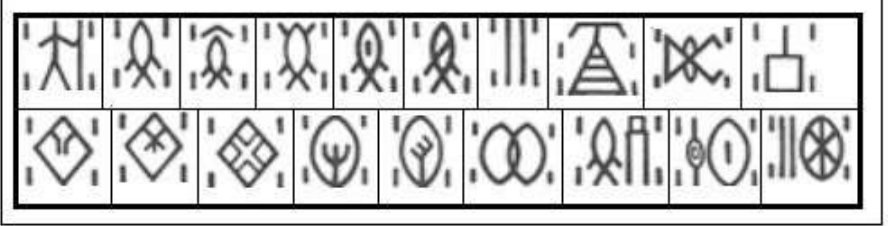

As shown in Fig. 3A, the Phrase-final-type-1 (PF1) signs almost always occur in the terminal positions of Indus semantic phrases, and barring a few exceptions, the Phrase-final-type-2 (PF2) signs generally occur following either the Phrase-final-type-1-signs or the Phytomorphic Crop-like (CROP) signs in the terminal positions of inscriptions. The Pre-phrase-final (PPF) signs, as their class-name suggests, demonstrate a strong affinity towards the Phrase-final-type-1-signs, and precede the Phrase-finaltype-1-signs in almost all of their (PPF-signs') occurrences (Fig. 3A).

Indus inscriptions also use certain numerical (NUM) signs, many of which are graphically stroke-signs (Fig. 3D). These signs generally precede certain specific semasiograms. The patterns where often the same semasiogram gets preceded by different number of strokes in different inscriptions (Fig. 3C-D), strongly indicate that those semasiograms were getting quantified by the NUM-signs in some predefined way. Another class of quantifier signs are the Metrological (MET) signs (Fig. 2G). These signs generally occur in similar inscriptional contexts as the NUM-signs in inscribed seals, sealings, tablets and pottery vessels (Fig. 3C). Certain groups of MET-signs (e.g. $U, \cup, \mathrm{U}_{\text {\& }}, \mathrm{U}^{\prime}, \mathrm{U}^{\prime \prime}$, '"'F

) demonstrate shared numerical notations, as they are graphically constituted by putting different number of strokes inside their basic graphemes. Unlike the NUM-signs whose numerical values possibly vary depending on the context and the objects of quantification, the values of the MET-signs arguably remain constant and represent different denominations of certain metrological standards (conveyed through their basic graphemes $U$, Uf etc.) prevalent in ancient IVC (Ansumali-Bahata, 2019). The CROP-like (CROP) signs are graphically phytomorphic signs (Fig. 2D). 
They frequently occur in the terminal positions of Indus inscriptions (Fig. 3D), and demonstrate a strong affinity towards the NUM and MET signs.

Figure 3. Representative examples of typical usage patterns of Indus sign-classes:

(a) Phrase-final and Pre-phrase-final signs; (b) Connective-morphemes and Pre-connective lexeme signs; (c) Metrological and Numerical signs; (d) CROP signs; and (e) Encapsulated signs

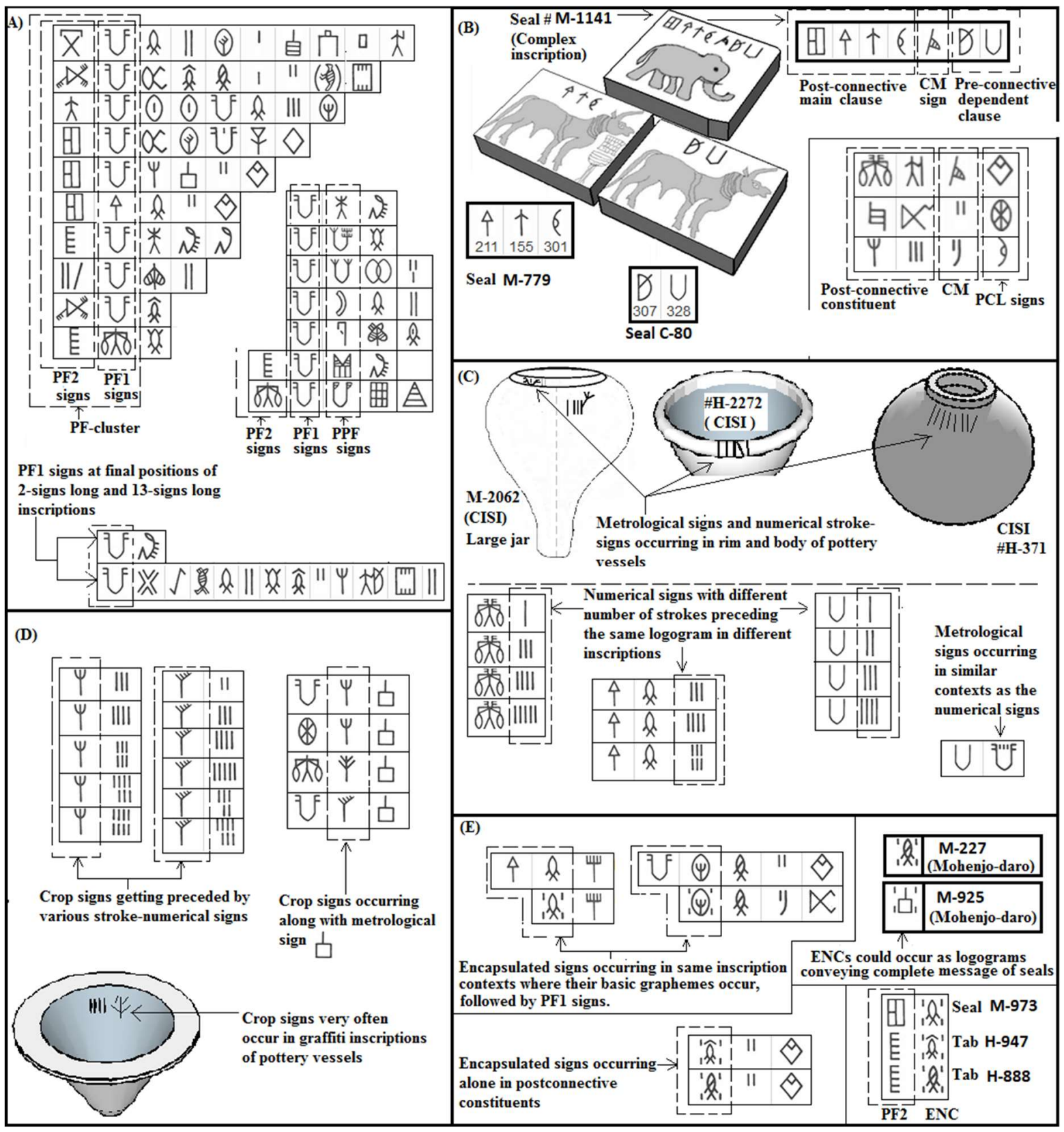


Interestingly the MET-signs and the Phrase-final-type-1-signs demonstrate a peculiar connection both in graphemic and combinatorial ways. For example, the MET-signs $\mathrm{UH}^{\prime} \mathrm{H}^{\prime \prime}$ and $\mathrm{IU}^{\prime \prime \prime}$ use the graphemes of the most frequent PF1-sign U. Now, in semasiographic scripts, the choice of similar graphemes for different semasiograms strongly indicates some underlying semantic connection between them. Moreover the MET-sign $\square$, which shows a strong association with CROP-signs (In all the inscriptions where CROP-signs occur, more than one-third inscriptions contain <NUM-CROP> constructs, whereas in more than 70 instances $\square$ precedes the CROP-signs), reveal an arresting combinatorial pattern. When preceded by NUM-signs, CROP-signs mostly occur in the terminalpositions, without any PF1-signs following them. But, when CROP-signs are preceded by MET-sign in $87 \%$ cases some PF1-sign follows the CROP-signs (e.g.

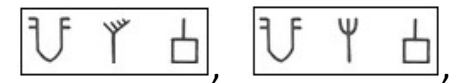
$818 \%$ etc.), indicating that in such contexts MET-sign semantically replaces the NUMsigns, and in doing so it needs PF1-signs to follow the constructs. This indicates an indirect semantic link between PF1-signs and metrology. The Indus signs classified as Encapsulated (ENC) signs stand out for their typical graphemic feature of having certain basic graphemes enclosed inside 4-stroke circum-graphs (Fig. 2I). As argued in Ansumali-Mukhopadhyay (2019), the ENC-signs are composite lexemes that assume both the semantic value of their basic graphemes and the functionality of Phrase-final-type-1-signs (see Fig. 3E).

As shown in Fig. 3B, certain Indus inscriptions are composite inscriptions, which can be considered as grammatically complex phrases, made of a dependent clause and a main clause, which get connected through a specific class of signs categorized as Connective-morphemes (CMs) or conjunctive signs (see Fig. 2C). As deducted by Ansumali-Mukhopadhyay (2019) the certain CM-signs are functional morphemes that play some kind of subordinating connective roles in complex Indus phrases, whereas some of them also occur as coordinating conjunctions in some composite inscriptions. The semantic scopes of the pre-connective dependent clauses and the post-connective main clauses are visibly different based on their distinctive sign usages. Often the pre-connective phrases are constituted of only single signs. There are around 100 distinct semasiograms that have occurred alone as pre-connectives in the inscriptions of around 1000 objects, among which the most frequent 5 signs $(\hat{\nabla}, \mathbb{Q}, 9, \mathbb{X}, \mathbb{W}$ ) have occurred as pre-connectives in more than $60 \%$ of these objects. The fact that only $5 \%$ of the signs occurred as pre-connectives in more than $60 \%$ of such objects irrefutably proves that certain signs were much more suitable to the semantic scope of preconnective constituents than others. These 5 signs and their allographs are classified as frequently pre-connective-lexemes or PCLs (see Figs $6 f$ and 7b). As argued in Ansumali-Mukhopadhyay (2019), both the pre-connective and post-connective constituents of any completely legible and undamaged complex inscription are semantically complete phrases. The pattern that the pre-connective constituents occur alone in the inscriptions much less frequently compared to the post-connective constituents, is arguably driven by the semantic role played by the pre-connectives in the domain of Indus inscriptions. Ansumali-Mukhopadhyay (2019) also establishes that there is generally no difference between the phrase-structures of long and short composite inscriptions (e.g. 

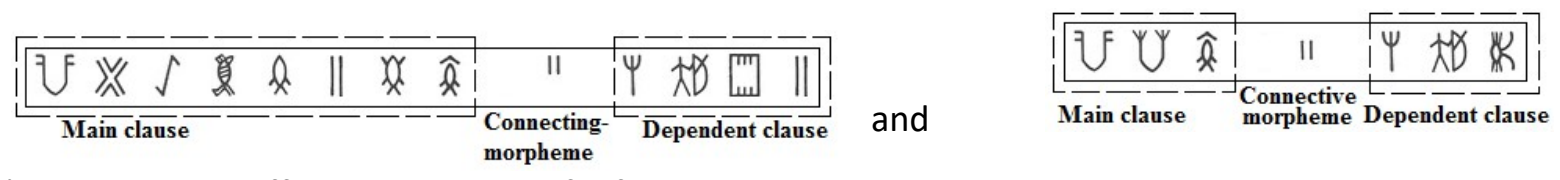

), as they only differ by the count of informational units contained in them. More importantly, this structural analysis explores a crucially important aspect of Indus inscriptions, i.e. their semantic compositionality, where the message of a comparatively longer inscription is constituted of the messages found in many other shorter inscriptions found in other inscribed artefacts. The 13-signs long inscription analysed in Fig. 4 , is visibly constituted of 5 such informational units that constituted the messages of many shorter inscriptions.

Figure-4. Demonstrating the semantic compositionality of a 13-signs long composite inscription

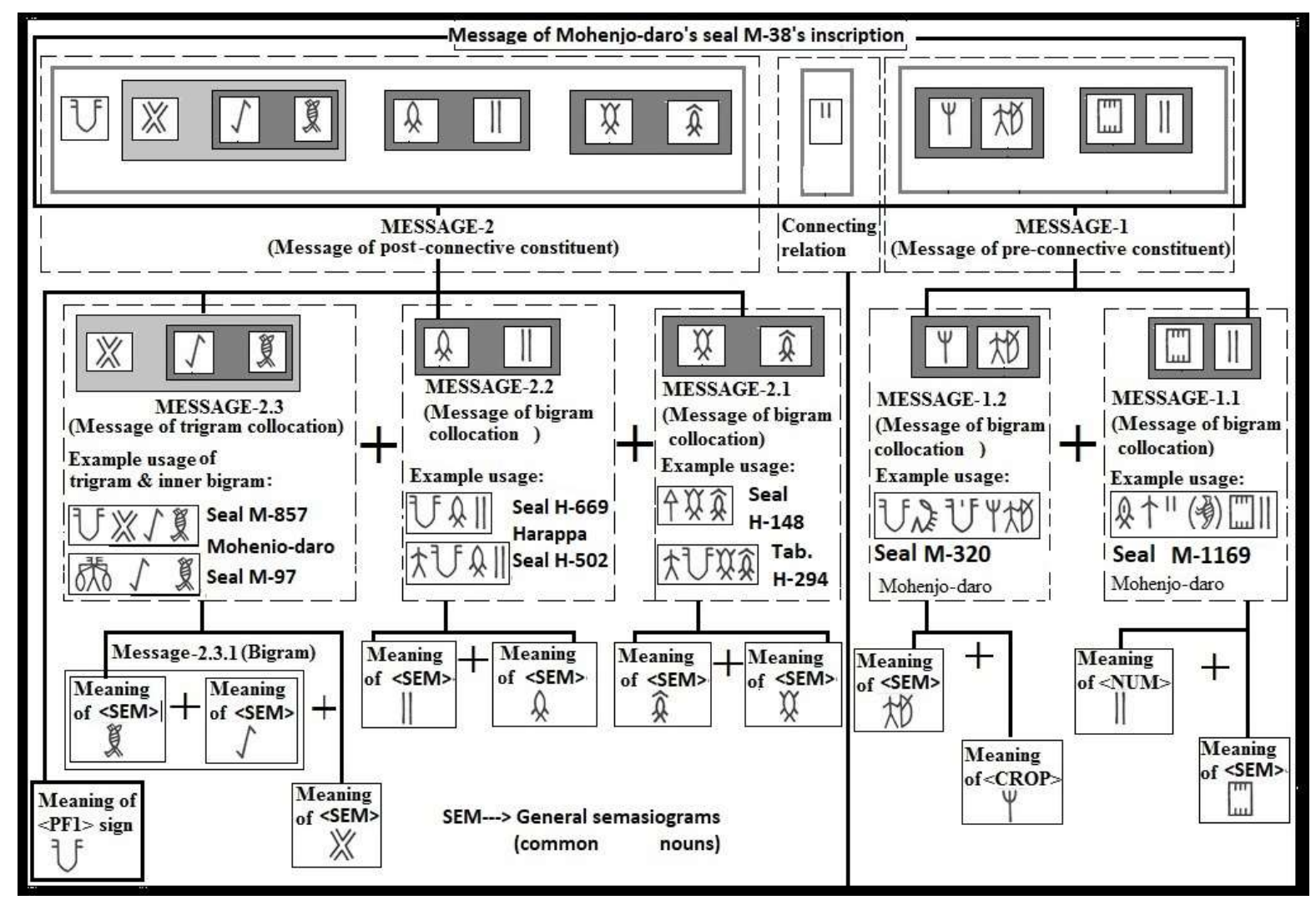

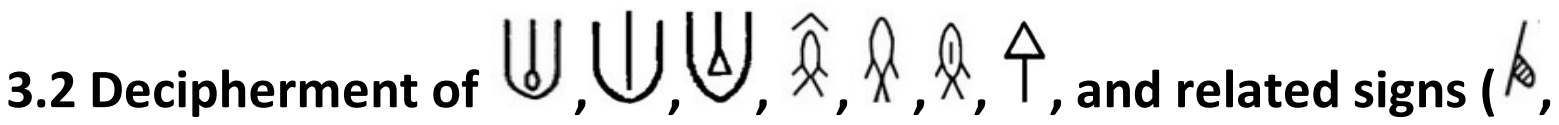
..)

\subsubsection{Decipherment of the Blowpipe-In-Crucible signs}

The most direct decipherment made in this study is the decipherment of the sign (d) and its allographs $(\bigcup \bigsqcup$, etc.), which visually symbolize a stick or rod put inside a vessel. This sign is generally interpreted by Indus scholars as a mortar-pestle sign related to agriculture (Mahadevan, 
2006). However, I have identified sign (d) to symbolize a blowpipe inside a crucible, depending not only on its visual similarity with those objects (see Fig. 5a), but also on its unmistakable association with the archaeological and inscriptional contexts related to gold-smithy, copper-smithy, and jewellery work. One such example comes from Mohenjo-daro, DK area Block 1, house VI, Room 52 (Mackay, 1938:452). Based on the presence of metal castings of blade axes, an irregular copper piece with saw-cut which was broken off from a larger mass of the metal, and close proximity of kilns, Mackay (1938) identifies this room and its surrounding as a place of metal-working. Interestingly, the blade-axes found from this room were "full of blow-holes", indicating the use of blow-pipe like instruments in the casting process. Moreover, Marshall (1931:198) refers to coppersmith's blowpipes found in Mohenjo-daro, whereas Rao (1979) repeatedly mentions pot-furnaces, rectangular brick furnaces, anvils, terracotta crucibles, and muffles used for copper-smithy in Lothal (p. 57, 84, $100,122)$. Thus, for Indus people, crucible-blowpipes must have been one of the most familiar instruments to associate with metal-smithy. Significantly, the seal (M-303, DK5307 411, ICIT \#2822) found from this room contains the text $\mathrm{T}\|\| \bigcup \|$, containing the symbol $U$. Now, as explained in Section-3.3, the Indus seal and tablet inscriptions were mostly used as tax-payment records for merchandise packages and as commercial permits. Thus these seal/tablet inscriptions are expected to contain the names of the taxed and licensed commodity-types. Thus an inscription found from a metal-smith's workshop is expected to contain messages related to taxation of metal artefacts, or license to manufacture metal artefacts. So it should contain semasiograms related to metals or metal-smithy. Now, in this inscription, there are two main structural segments (see Section-3.1 and Ansumali-Mukhopadhyay (2019) for the structural aspects of Indus-Inscriptions): i) the pre-connective part and the connective-morpheme $\| U$ Here, sign $\bigotimes_{\text {occurs in the pre-connective contexts of around } 150 \text { inscriptions with various }}$ different sign-sequences occurring in the post-connective segments. Thus, semantic scope, and is not the likely candidate to associate to the specific context of metal-smithy.

Similarly, the terminal sign 9 occurs in almost 311 inscriptions recorded in ICIT. As discussed by Ansumali-Mukhopadhyay (2019), this class of terminal or phrase-final signs have a generic semantic scope applicable to large number of inscriptions. Thus, excluding these semasiograms, the sequence $\|\mathbb{U}\| \mathbb{U}$ is a frequent collocation used in Indus-Inscriptions) remain as the most likely candidate to associate with the specific context of metal-smithy.

Now, since crucibles and blowpipes were the most ancient and widely used smelting tools, they must have provided compelling visual images associated with metal-smithy and gold-smithy. As shown in Figs. $2 a$ and 2b, goldsmiths across the ancient world, be it ancient Egypt or historical India, were invariably depicted as artisans using crucible and blowpipe. Thus, the visual similarity of

(allograph of $\left(\int\right)$ with the ancient blow-pipes and crucibles (Fig. 5a), along with its application in the archaeological context of metal-smithy, strongly suggests the metal-smithy/metal related meaning of this symbol. Intriguingly, even in Egyptian hieroglyphic writing, the symbols of "an artisan using a blowpipe and a crucible" are used as determinatives to denote (i) "smelter, foundryman, 
goldworker, goldsmith" ("nubi" "d craft" ("nub-t" 366), proving the applicability of crucible-blowpipes as symbols of gold-smithy across ancient cultures.

Figure-5. Iconicity, linguistic association and script-internal evidence regarding the decipherment of the crucible-blowpipe signs and the arrow sign

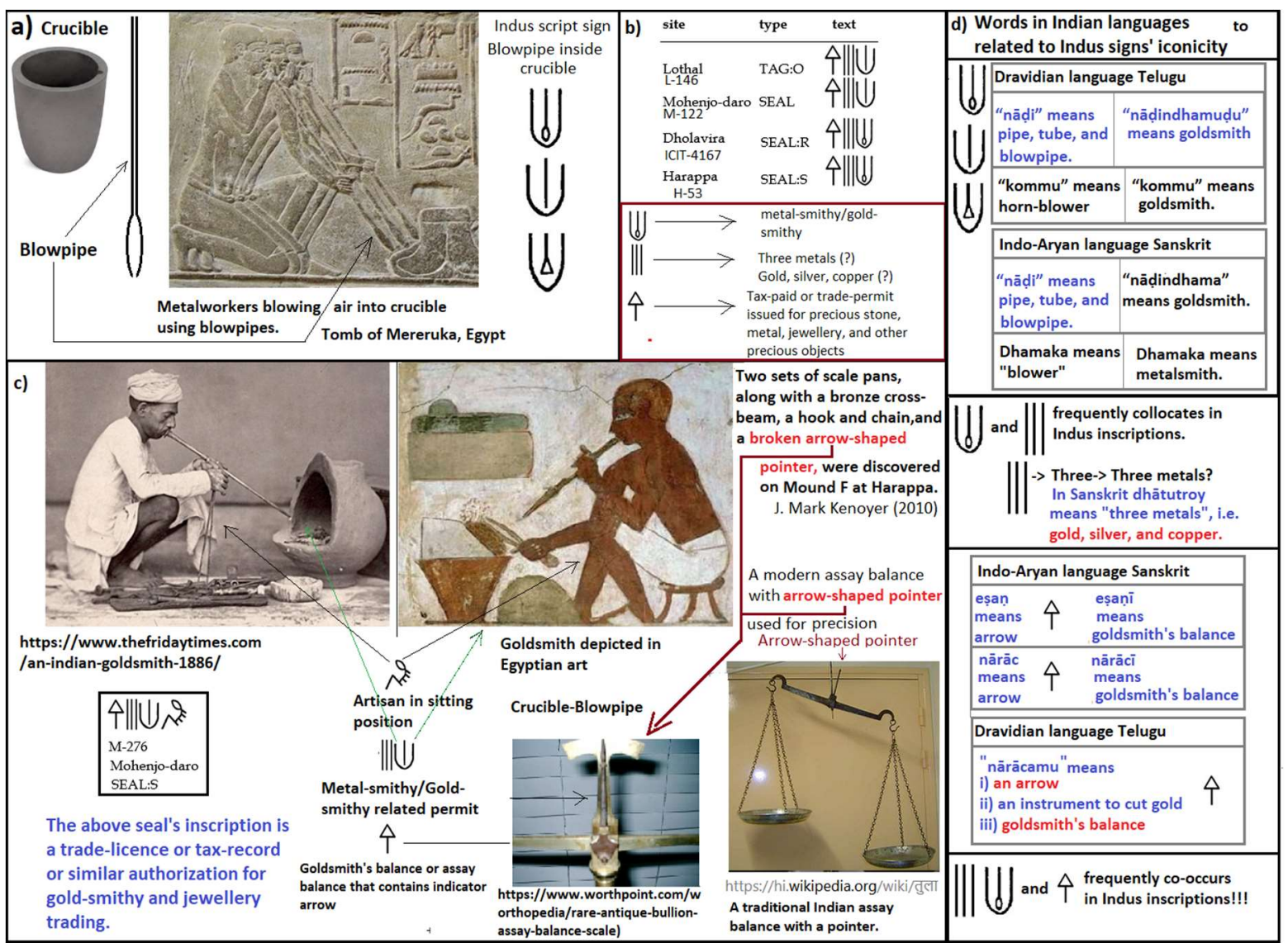

Moreover, as shown in Fig. 5d, various Indic languages have used words for gold-smith (e.g. "kommu", "nāḍindhamuḍu", "nāḍindhama") that are etymologically related to the words for blowing and blowpipe ("dhamaka", "nāọi", etc.) (Brown, 1903; Haughton, 1987). Even in Arthaśāstra (c. 400 $B C$ ), the word "dhmāyaka" meaning "blower" is mentioned in the context of goldsmiths' shops and related artisans - "Goldsmiths who are engaged to prepare various kinds of ornaments, such as kāñcana (pure gold), prșata (hollow ornaments), tvașțr (setting gems in gold) and tapanīya, as well as blowers and sweepers, shall enter into or exit from the office after their person and dress are thoroughly examined" - (Shamasastry, 1929, p. 91). 


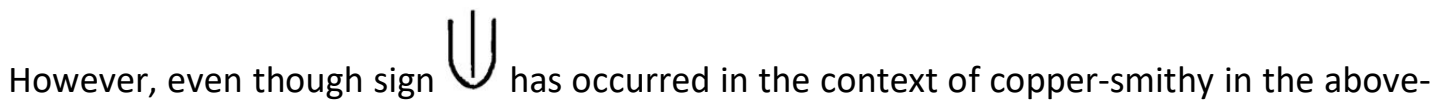
mentioned scenario, and sign (d) has occurred directly on a copper spear-head (C-38), in most cases the crucible-blowpipe signs occur in the inscriptional and archaeological contexts of gold-

smithy, and jeweller's workshop, along with fish-signs. As recorded in ICIT corpus, and occur in 215 and 102 inscriptions totally, among which they occur along with Fish-signs in 98 and 74 inscriptions respectively. The semantic association of the fish-like signs with the meanings of bead, bead-making, precious stones, and lapidary craft, is established in Section-3.2.2 below. Interestingly, the crucible-blowpipe sign 10 even directly occur on an inscribed gold object (M-2128), that looks like an end-mill or burnishing tool used in jewellery making. Considering the association of crucibleblowpipe symbol with gold-smithy in ancient cultures; the linguistic words used for gold-smithy that are etymologically rooted to the meanings of blowpipe and blowing; and the strong correlation between signs (d) U with bead and jewellery related fish-signs, I claim that (d) and its allographs denoted gold, precious-metals and gold-smithy, and the generalized meaning of metalsmithy, depending on the context.

\subsubsection{Decipherment of the fish-like signs}

Here, I shall discuss how the fish-signs repeatedly occur in inscriptions found in the archaeological contexts of bead-makers' and jewellers' workshops across Indus settlements, proving their relation with such crafts, and how the crucible-blowpipe signs often accompany the fish-signs in such contexts to signify taxation and trade-permits related to gold-smithy.

\subsubsection{A Archaeological evidence regarding the correlation between fish-signs and bead- making}

A great evidence of the semantic relation of fish-sign $\chi_{\text {with jewellery workshops come from }}$ Mohenjo-daro. Marshall (1931:194-195) describes an 8-by-7 feet room found in Mohenjo-daro, part of House-VIII in HR Area, which "yielded the most important find of the season". In this room coexisted silver and copper vases, a copper axe and chisel, various gold and silver ear-ornaments, bangles, diadems, fillets, pins, unfinished ornaments, "a large collection of beads of gold, silver, faience, semi-precious stones, mounted in some cases in gold caps at both ends, and pendants of different materials", along with perforated spacers and hemispherical ornament terminals. Since a chart scraper and unfinished ornaments are found from this room, it cannot be a personal treasury of a wealthy person, but is surely a jeweller's shop. It is simply not possible that so many items linked to bead-making and jewellery had landed over the same room from different stratigraphic layers. Now, since Indus seals were mostly used for tax-stamps and commercial permits (see Section-3.2), when we get a seal (M-294) in such a specific archaeological context of a jeweller's shop, we can 
safely semantically link its inscription with jeweller's craft and related taxation and trade-license. This seal with an unusual iconography containing both a unicorn and an elephant, also contains the

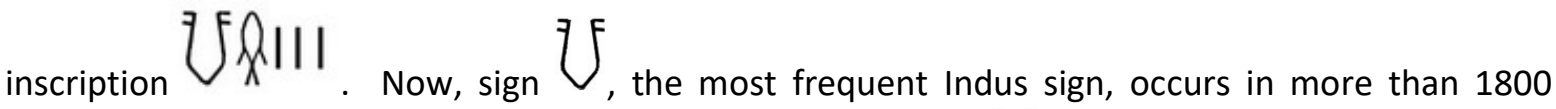
inscriptions. As discussed by Ansumali-Mukhopadhyay (2019), $U_{\text {being a terminal or phrase-final }}$ sign, it is associated with the most general semantic scope of Indus-inscriptions. Similarly the numerical sign $\mid \mathrm{I}$ also occurs in varied inscriptional contexts, most possibly as some kind of a quantifier. Thus, the remaining fish-sign $X$, should most possibly be associated with the semantic context of a jeweller's shop. Now, as would be discussed in detail below, the Indus valley precious stone beads, which were extremely coveted in ancient Near East, were famous as "fish-eye beads" in Mesopotamia (Donkin, 1998; Howard-Carter, 1986:305-310). Thus, since beads made of precious stones, often bearing eye-patterned designs, were the most prized commodity-types present in an Indus valley jeweller's workshop (other than gold, which gets signified by the crucible-blowpipe signs), the correlation of the fish-sign 4 with beads, becomes a strong possibility. As discussed below, excavation reports of Chanhujo-daro and Harappa confirm this correlation between inscriptions with Fish-signs and the archaeological contexts of bead-making and jewellery workshops.

In Harappa, Vats (1940 pp. 58-60, 435) reports the finding of "a number of instructive antiquities, including a representative collection of jewellery" (Series No. 8650), comprising a large number of incised tablets and seals; numerous objects of stone, faience, gold, and copper; shells; two small cubical weights ( 26.3 and 4.3 grams); and a large collection of beads (of various shapes and sizes, made of gold, carnelian, steatite, faience, shells, etc.). All these artefacts were discovered in squares H-12/21 and I-12/1 of Mound-F Stratum-IV where "a well and fourteen Workmen's Quarters of peculiar design" was also found. Here, the presence of a large collection of beads, small weights, and workmen's quarters indicate that this place was an important lapidary workshop. Now, as expected, among the 14 tablets and seals found from this location, 9 tablets and 1 seal contain the fish-signs, confirming the Fish-sign-Bead-making correlation (see Fig. 6).

Similarly, in Chanhu-daro, which was a very important commercial Indus settlement, "[b]ead-making was an important source of revenue. Large numbers of unfinished beads, together with the stone drills used for boring them, were taken from Squares 8/C, 9/C, 9/D, and 9/F" (Mackay, 1943). Here, "supplies of the raw materials for bead-making were also unearthed; in several cases nodules of agate showed signs of having been treated with heat" (Mackay, 1943). "There were also lumps of amethyst, crystal, and carnelian" (Mackay, 1943). Mackay has specifically mentioned a house in 9/D, where he describes a "small room" (7 feet 7 inches by 3 feet 2 inches), numbered 174 , which "may possibly have been a little workshop, for many unfinished beads were found there at the level +6.8 feet and also a seal $(2297, \mathrm{PI}-\mathrm{LI}, 29)$ at a slightly lower level". This seal (ExcavationId 2297, CISI C-10) again contains the text the fish-signs with the bead-maker's craft. Mackay (1943) has admirably pointed out which excavated areas of Chanhu-daro were related to bead-making, shell-working, metal-smithy etc. I have provided a contextualized diagram of the inscribed seals and tablets found from these specific sections of Chanhu-daro in Fig. 7. Often, metal-smiths, lapidary-workers, and shell-cutters worked 
in the same houses. For example, in Square-9/D, inside Room-215, various unfinished beads (meant to be glazed), copper-tools, copper and bronze knives, a copper pin, a flake drill, a faience gamesman, a queer shell object, and some carnelian nodules were found in the same level $(+10.4$ feet). Moreover, 14 weights and scale-pans of copper were also discovered and an additional weight was found in a nearby furnace-room.

Figure 6. Contextualized diagrams of inscriptions of seals and tablets found from a Harappan lapidary workshop. (Objects with fish-sign inscriptions are marked with orange borders).

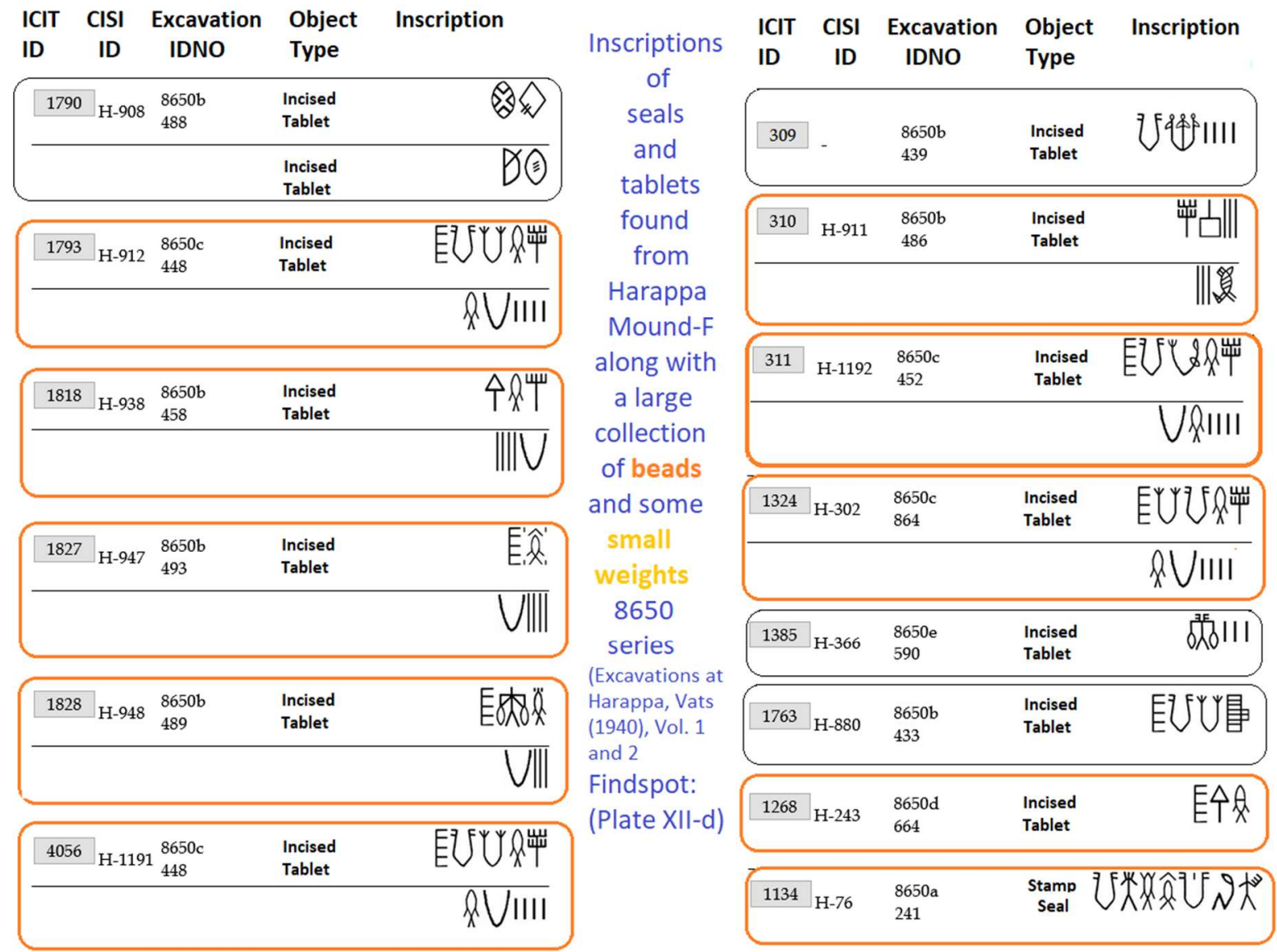

Two large shells were also present here, indicating that "shell working was also practised in this workshop" (Mackay, 1943, p. 43). Mackay has identified this building (comprising locations 215, 286, and 287) as a "bead factory with furnace". Now, Seal-C-65 (Excavation-Id CH-2428) was found here, on the floor of passage 286, and it contained text Working correlation. Moreover, square-9/D of Chanhu-daro is specifically identified as bead-maker's area, and we can see that out of the 9 inscribed seals found from 9/D, six seals have fish-signs in them, further corroborating the proposed correlation of fish-signs with bead-making (Fig. 7). Moreover, in the seal inscriptions found in $8 / \mathrm{D}, 8 / \mathrm{E}$, and $12 / \mathrm{K}$, both the crucible-blow-pipe semasiograms related to gold-smithy and the fish-signs related to bead-making co-occur (see inscriptions marked by both yellow and orange borders in Fig. 7). Thus, as expected, the relationship between bead-making and gold-smithy got recorded in these inscriptions, which were used as tradepermits and tax-stamps (see Section-3.2) related to jewellery. 
Fig. 7 Contextualized inscriptions of Chanhujo-daro: Inscriptions found in specific contexts of metal-smithy, lapidary-work, shell-work, etc.

Contextualized inscriptions of Chanhujo-daro.

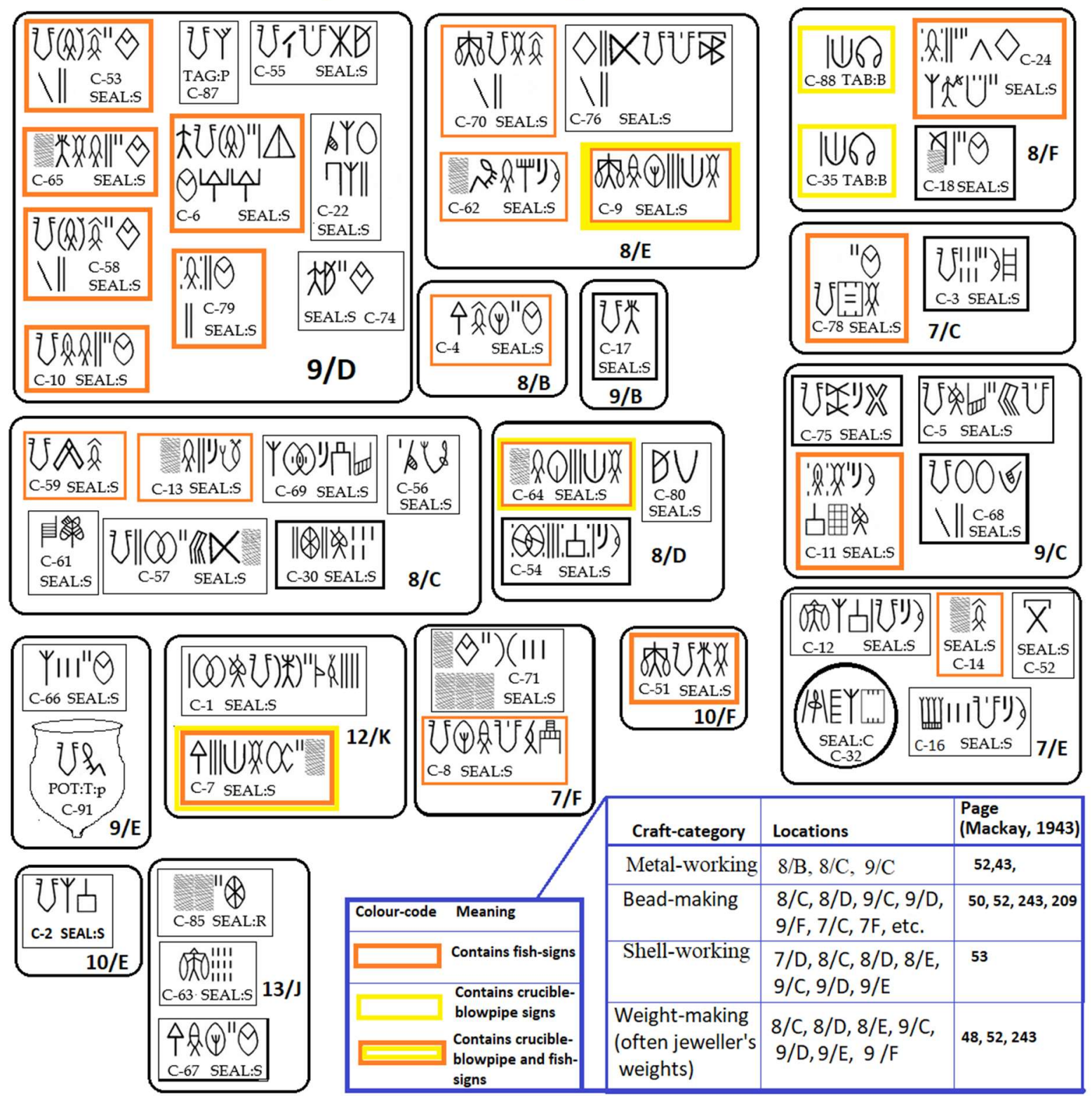

3.2.2B NA $\mathrm{B}_{4}-\mathrm{IGI}-\mathrm{ME}-\mathrm{LUH}-\mathrm{H}_{\mathrm{A}}$ and Mani: Linguistic, cultural and historical contexts of using Fish-signs' iconicity to signify bead-making related meanings

Unlike the case of Crucible-Blowpipe signs and their linguistic association with gold-smithy, the linguistic and cultural basis of beadmaking's fish-related iconicity was not so obvious, and needed more research. To unravel the fish-symbolism in Indus culture, this study engages with the apotropaic words used for the most important craft-commodity of Indus civilization, the beads. 
Precious stone beads imported from IVC were highly prized commodities in Persian Gulf and West Asia. Thus beads were among the most specialized craft items and trade commodities of IVC, having a crucial place in IVC's economy. Relevant in this context is Vidale's (2004:271) remark:

"Just to give an impression of the possible cost of an Indus necklace or belt made of long barrel-cylinder carnelian beads, on the basis of experimental replications we calculated that the production of one of these ornaments roughly amounts to 480 days of work by an highly skilled artisan ... No wonder that such precious beads were actively sought for and monopolized by the Sumerian elites".

Analysing IVC's industry-scale bead-production systems, Kenoyer (2013) too comments:

"The use of shell beads with concentric circular patterns that could be interpreted as eyes begins around 7000 BC at sites such as Mehrgarh. Later, during the Regionalization Era or Early Harappan Period, new forms of eye designs were created using natural stones and also carved steatite beads and button seals. The use of eye motifs became more widespread during the urban period and continued to become more elaborate during the late Harappan and Early Historic periods."

Several texts of ancient Mesopotamia, including the ancient Mesopotamian lexicon "HARra=hubullu", have documented "fish-eyes" ("IGI-KU ${ }_{6}$ " and "IGI-HA"), "Eye-stones" of Meluhha ("NA ${ }_{4}^{-}$ IGI-ME-LUH-HA"), and "fish-eye-stones" ("NA$A_{4}-\mathrm{IGI}-\mathrm{HA}$ ", "NA $4-\mathrm{IGI}_{-}-\mathrm{KU}_{6}$ ") among the treasured import items of Mesopotamia (Donkin, 1998; Howard-Carter, 1986:305-310). Donkin (1998:50) refers to a scholarly consensus that the "fish-eye", "fish-eye-stones" and "eye-stones" in old Mesopotamian texts refer to the etched carnelian beads and pebbles of banded agates, which were "cut to resemble closely a black/brown pupil and white cornea", and were imported from northwest India. As documented by archaeologist Howard-Carter (1986:305-306), the pedagogical texts taken from tablets of Sultantepe give irrefutable explanation of the etymology of "fish-eye-beads". The texts instruct that the "name of a stone which looks like a fish-eye is fish-eye stone"; and the "name of the stone which looks like a snake's eye is snake-eye stone". Carter also clarifies that though eyestones got their first textual references in the Akkadian version of the "descent of Ishtar", their first archaeological appearance was in the Indus valley trade-port location in Lothal. Even in modern days, eye beads or eye-shaped amulets, used as talismans against the so-called "evil-eye", are prevalent in Turkey, India, and many other places. These beads are famous as "Drșți" ('Drșți' means eye-sight or glance in Sanskrit) and "Nazar" (eye-sight in Arabic) amulets. While analysing the "dramatic increase in methods to create eye designs during the Integration Era" of IVC, Kenoyer (2013) states that, this phenomenon "cannot be explained simply as a growth in technical expertise", and hypotheses that Indus fish-eye beads possibly had a similar ethno-historical significance of "protective amulets".

The significance of fish as an apotropaic amulet against evil-eye possibly stems from the fact that "evil-eye" being supposed to cause "drying, desiccation, withering, and dehydration" in many cultures, "fish are thought to be immune from evil-eye as they are always wet" (Pitts-Taylor, 2008: 111). Another relevant ancient symbolism prevalent among Semitic people of ancient Persia is the comparison of fish-eye to the God's watchful eye, as both never shut, and hence symbolize divine protection (Frankel and Teutsch, 1992). These are the possible reasons why fish are very often portrayed in evil-eye talismans. Interestingly, in ancient Mesopotamian medicine, the "fish-eye stone", "papparminu-stone", lapis stone and carnelian were mentioned as parts of 13 stones that were used as talisman against waning hair. The "pappardilû" and "papparmīnu" stones were also prescribed to be used as stone charms against ghost-induced pain (Scurlock, 2014). But pappardilû and papparminnu were banded agate stones with one and two white bands respectively (Parpola S, 
2007), and as mentioned before, etched carnelian beads and banded agates were known as "fisheye stones" and "eye-stones" (Donkin, 1998) in ancient Mesopotamia. Thus it is evident that banded agates were indeed used as talismans against evil forces.

Even in Christianity, the term "ichthys", meaning "fish", is considered as a very powerful apotropaic (Elliott, 2017), and it occurs in various amulets. Intriguingly, excluding the fish fins, the grapheme of the fish-sign x closely resembles $\propto$, the symbol of ichthys. Finally, a very intriguing Indic traditional symbolism that directly associates "fish" with "eye" is found in the Buddhist Aştamangala signs, where the symbol of two golden fish or "gser nya", represent Buddha's eyes "with which he gazes at the world with compassion" (Reis \& Hibbeln, 2006).

Based on the above evidence, this study affirms the linguistic and cultural basis of using fishlogograms to denote "fish-eye-beads" or more generally "eye-beads", which having been ascribed with some apotropaic role in the ancient civilizations, were very precious traded commodities, and hence were potential taxable commodities of IVC. The different markings in the fish logograms possibly denoted the variation of materials or sizes of these beads, since depending on the material and type of bead the rates of taxes were expected to vary.

In my quest to find out which ancient Indian word had the semantic association between "eye" and "precious stone beads" or gems, the word "mani" came up as a strong candidate. In the context of analysing Asia's maritime bead trade, Francis (2002) shows how the Sanskrit "Mānikya", Tamil "Maṇikam", Hindi "Maṇi" and "Māṇek", Malay and Indonesian "manik" and "manik-manik" (plural), are all words meaning "bead", "beads" (plural), and "precious-stone". The ancient Tamil Sangam literature "identifies beadmakers or gem-workers as tirumaṇi kuyinar and maṇi vinaiar", while the Indo-Iranian word "mani" meant "seed, precious-stone, and sperm" (Francis, 2002). As Turner (1999) documents in his comparative dictionary of Indo-Aryan languages, in various languages, such as Pāli, Prākrit, languages of "Kharoșțī" inscriptions found in Chinese Turkestan, Panjābī, Lahndā, Marāțhī etc., the word "mani", along with its close derivatives, meant "bead" and "gem". But both in the Indo-Aryan languages and Dravidian languages such as Tamil, "mani" also meant "pupil of eye" or "apple of the eye", whereas in both Tamil and Sanskrit, "mani" additionally means "amulet" and "a supernatural gem" (Turner, 1999; Tamil lexicon, 1924-36). In Sinhalese, "manin" and "mina" meant gems, jewels, and precious stone (Clough, 1892), whereas "mina" meant fish, zodiac Pisces and a sort of gem. In Atharvaveda, multiple usages of the word "mani", cover all kind of amulets made from different herbal and mineral products, used as protective charms, counter-witchcraft products, and magical instrument of attack (Bloomfield, 1899). Thus the word "mani" encompasses the meanings of bead, stone, eye and protective amulets, strongly demonstrating the ethno-historical interconnection between these words. The strongest and almost irrefutable linguistic corroboration regarding the ancient origin of "mani", comes from the letters of "El-Amarna Correspondence" (Rainey, 2014), which repeatedly refers to the Akkadian "maninnu" necklaces, which the Mitanni king Tushratta sent as gifts to his son-in-law, the Egyptian king "Nimmureya", in fourteenth century BC. As Parpola (2015) has identified, "The Akkadian word maninnu (with its Akkadian suffix -nnu) contained in this text is one of the few Mitanni Indo-Aryan words that have been etymologically identified: corresponding to Vedic maní, "necklace" (Rigveda 1,122,14; and maṇi-grīvá-, "wearing a maṇi-necklace on one's neck")". Thus these "Maninnu" necklaces mentioned in Tushratta's letter were undoubtedly "Manihara" or "bead-necklaces", as each of them was described as containing lapis lazuli beads and other precious stones ("bulalu", "hiliba" etc.) mounted in gold. Hence it is evident that the word "mani", which simultaneously meant "pupil of eye", "bead" and "precious-stone", was used over a long stretch of time across distant 
geographical locations. With these archaeological and linguistic corroborations this paper affirms that the calquing of this common word in otherwise dissimilar languages is very surely traceable to the prehistoric "eye-bead" trade, dominated by the IVC people, and the fish-signs were the deserving symbols of IVC's bead-making related meanings.

\subsubsection{Meanings of different Fish-signs, material-based bead categories, bead-related metrological unit and currency:}

Indus fish-signs (Fig. 5a) occur in around 966 distinct inscriptions recorded in ICIT. Often more than one fish-sign occurs adjacently in the same inscription ( $\mathrm{A}$. $\mathrm{x}$ Xll as in seal H-1678). Now, though all the fish-signs had meanings related to bead-making, jewellery and lapidary craft, how their

individual meanings differed from each other is difficult to guess. Among the fish signs, sign

220

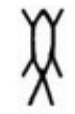

(total 475 occurrences) is the most frequent one. Other frequent signs are: 240 (350 occurrences),

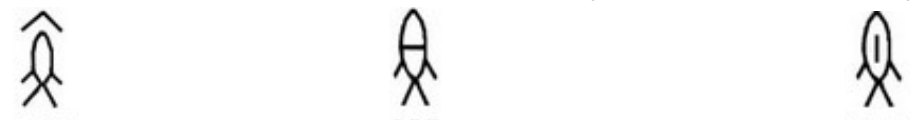

235 (248 occurrences), 233 (191 occurrences), and 231 (90 occurrences). Since the IVC people made beads from very different materials, such as gold-beads, copper-beads, precious-stone beads made of lapis lazuli, carnelian, agate, onyx etc., and less costly beads made of steatite and faience, some of these fish-signs could signify such broad-categories of beads (gold and lapis lazuli beads, other precious-stone beads, beads made of less costly materials such as copper, faience, steatite etc.) as the price of their raw materials would widely vary, and hence there would be related types of taxation, and trading and manufacturing licenses. Some other variations (see Fig. 5a) could have meant permits for different bead-making activities such as cutting, glazing, etching etc., though it is less likely.

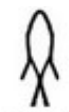

After this fishy note, I propose that, sign $\mathbf{2 2 0}$, which is the most frequent fish-sign, possibly signified a specific bead-related metrological unit, as it is the only fish-sign that is often preceded by<smiles>C1CC1</smiles>

numerical stroke signs. For example, in around 131 inscriptions

220 is preceded by different stroke-numeral signs: in 68 inscriptions preceded by $\left\|_{\text {; in } 6 \text { inscriptions by }}\right\| \|_{\text {; in } 20 \text { inscriptions by }}$

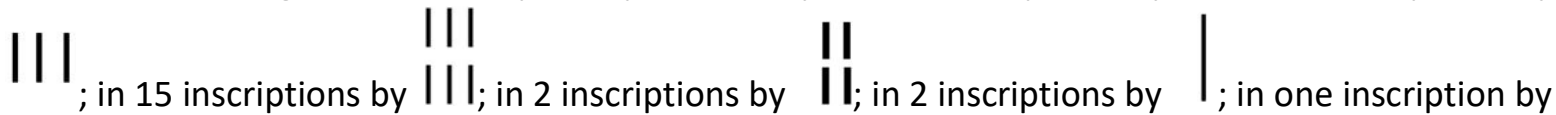

IIII

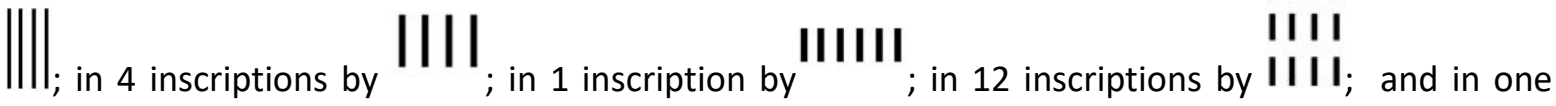
inscription by III 

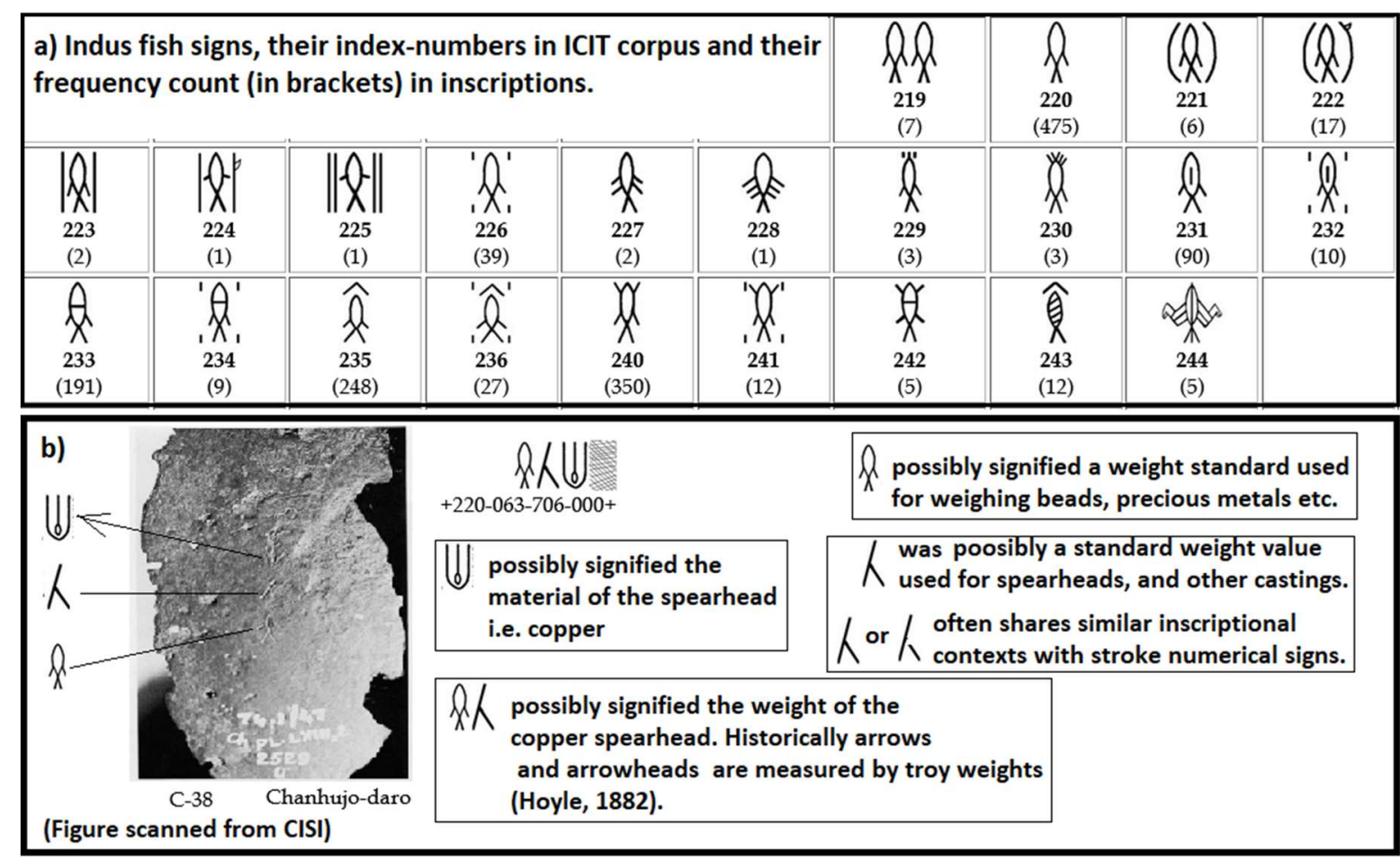

But the other fish-signs very rarely get preceded by Stroke-numerical signs. Thus, possibly, 220 signified the general meanings of bead-making and related commodity-types, and the standard metrological unit used to weigh/measure beads. Thus, its preceding numerals possibly denoted fixed tax-rates (some fraction of the standard unit).

$$
\lambda
$$

Revealingly, 220 also occurs in copper implements such as spearheads (see Fig. 5b). Here it possibly signified the weight of the spearhead. Copper spearheads, arrows, and other copper-bronze implements must have been costly items and thus must have been minutely weighed using the weight standard used for precious commodities. Historically, troy weights are used to weigh arrows (Hoyle, Edmond. Hoyle's Games. Longman, 1882, p. 291).

\subsubsection{Some other signs related to metal-smithy}

Many other interesting clues emerge from the contextualized inscriptions of Fig. 4. For example, Mackay (1943, page 52) has specifically identified the squares $8 / B, 8 / C$ and $9 / C$ to be concentrated working area of metal-smiths, whereas square $9 / D$ too has yielded many metal-working artefacts. In square-8/C, Courtyard-297 contained a number of copper and bronze tools, an ingot of bronze, and bangles and razors, all of them products of the metal-worker's craft (Mackay, 1943). Now, both in Square-8/C and Square 9/D, we get seals (C-22, C-56) with inscriptions

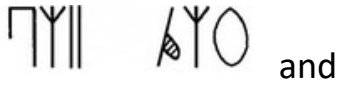
'ble respectively, containing the axe-like symbol ${ }^{2}$. Moreover, in Square-9/C, we get the sign 
| inside a crucible. Thus, the axe-like sign could have had a strong correlation with metal-smithy, and could have represented "casting of copper tools and weapons".

3.2.4 Decipherment of 4 , and interpretation of other terminal signs $(1,8,3$ etc.)

I have already mentioned that the terminal arrow-like sign $\uparrow$, which mostly occurs in inscriptions containing bead-making and metal-smithy related semasiograms, arguably symbolized goldsmith's balance, and metonymically signified tax-payments and trade-permits associated with precious stones and metals. This is one of the most important deciphered symbols of this paper. But to understand the logic of its decipherment, we need to first analyze the semantic scope of the semasiograms that frequently occurred in the terminal or phrase-final positions in Indus inscriptions. Then we need to specifically analyze that semantic scope of $T$, to explain why it so repeatedly shared archaeological and inscriptional contexts with the gold-smithy and bead-making related semasiograms. Accordingly, I shall first interpret the semantic scopes of the PF1 terminal signs \$18, etc. which often occur in similar inscriptional contexts as sign 4 . Next, I shall show how the decipherment of $\triangle$ matches the general semantic scope of these terminal signs, and completely

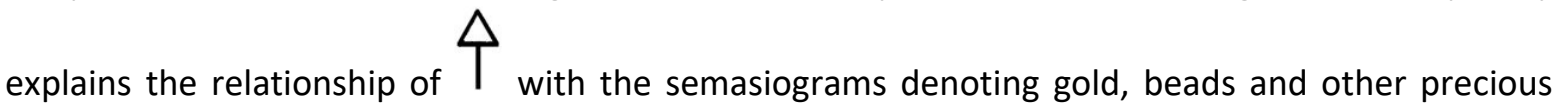
commodities and the related crafts.

\subsubsection{A Semantic role of the Phrase-final-type-1-signs: Metrological units and names of broad tax categories}

Section-3.1 already explains the key structural aspects of Indus-Inscriptions, and the role of the PF1signs in the phrase-structure of Indus-Inscriptions. Here I propose that these PF1-signs denoted certain types of metrological systems (volumetric, weigh-based etc.) and corresponding mensural units used in the tax collection. Considering the close relationship between the revenue-standards and metrological standards in the barter-based economies of ancient moneyless societies, this study proposes that the PF1-signs were used as generalized metonyms of certain broad categories of taxes.

I build the PF1-Hypothesis on the graphemic and combinatorial relationship shared by the PF1 and MET-signs; the graphemic feature of MET-signs that semantically associates them with the metrological vocabulary used in ancient India; the close relationship between the revenue-related nouns and metrological nouns used in ancient barter-based economies across the world; and on the tendencies of the metrological nouns to get used across a large geographic region, along with their capability to sustain their meanings for thousands of years (Kula, 2014). 


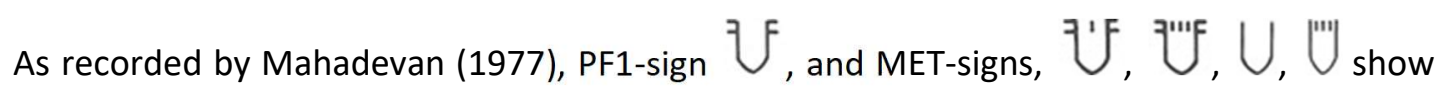
certain graphemic variations in different inscriptions (see Fig. 9). Even a cursory look those graphemes would persuade us that signs $\mathcal{W}$ and $U$ closely resemble certain rimmed and rimless vessels, jars or pitchers. On the other hand, the PF1-sign $\$ 18$ unmistakably symbolizes a "loadbearer" pictograph, showing a man holding equal amounts of weight on either side of his shoulderpole. The PF1-signs 818 and 810 are respectively constituted by combining the graphemes of the arrow-like PF1-sign $\uparrow^{\top}$ and the jar-like PF1-sign $\mathcal{J}$, with the load-bearer grapheme of sign $8 \mathrm{AO}$. In some instances, the load-bearer grapheme also seems to resemble a pan-balance. Though AnsumaliMukhopadhyay (2019) has identified the MET-signs mainly based on their combinatorial patterns and archaeological contexts, this semantic study will now establish that the MET-sign symbolisms were arguably connected to the metrological vocabulary used in ancient times.

Concentrating first on ancient volumetric units, it is found that almost all the traditional units of volume were named after various kinds of vessels, jars and troughs used in ancient India. As documented in Arthaśāstra (c. $400 \mathrm{BC}$ ), the main metrological units used in its contemporary period for capacity measurement (some used in both weight and capacity measures) were "kuduba", "prastha", "āọhaka", "droṇa", "khāri", "kumbha" and "vaha". Interestingly, almost all of these words also mean certain types of vessels in Sanskrit. For example, "drona" means "a wooden vessel, bucket, trough" etc., "kumbha" means "a jar, pitcher, water-pot" etc. (Monier-Williams, 1872). While "prastha" and "kuḍuba" /"kuḍava" primarily mean particular grain measures, they also signify containers or vessels having those capacities (Monier-Williams, 1872). Interestingly, terms like "drona", and "kumbha" were also mentioned in Rigveda with the same meanings, respectively "wooden trough" and "pot", whereas "khāri" designated "a measure of Soma in one passage" (Macdonell and Keith, 1912). These evidences clearly show that the metrological terminologies prevalent in the Rigvedic era were used in the time of Arthaśāstra as well, and they were semantically and linguistically associated with the names of the vessels used in this era.

Figure 9. Graphemic variations of certain metrological and phrase-final signs. Variations of (a) PF1

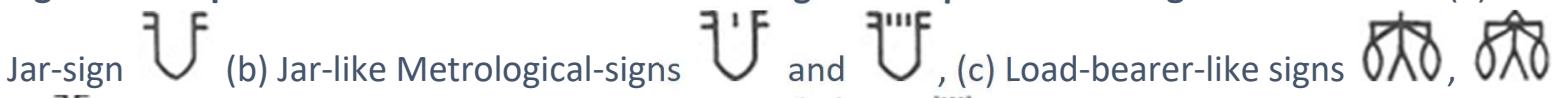
薃 and (d) Rimless-jar-like Metrological-signs 


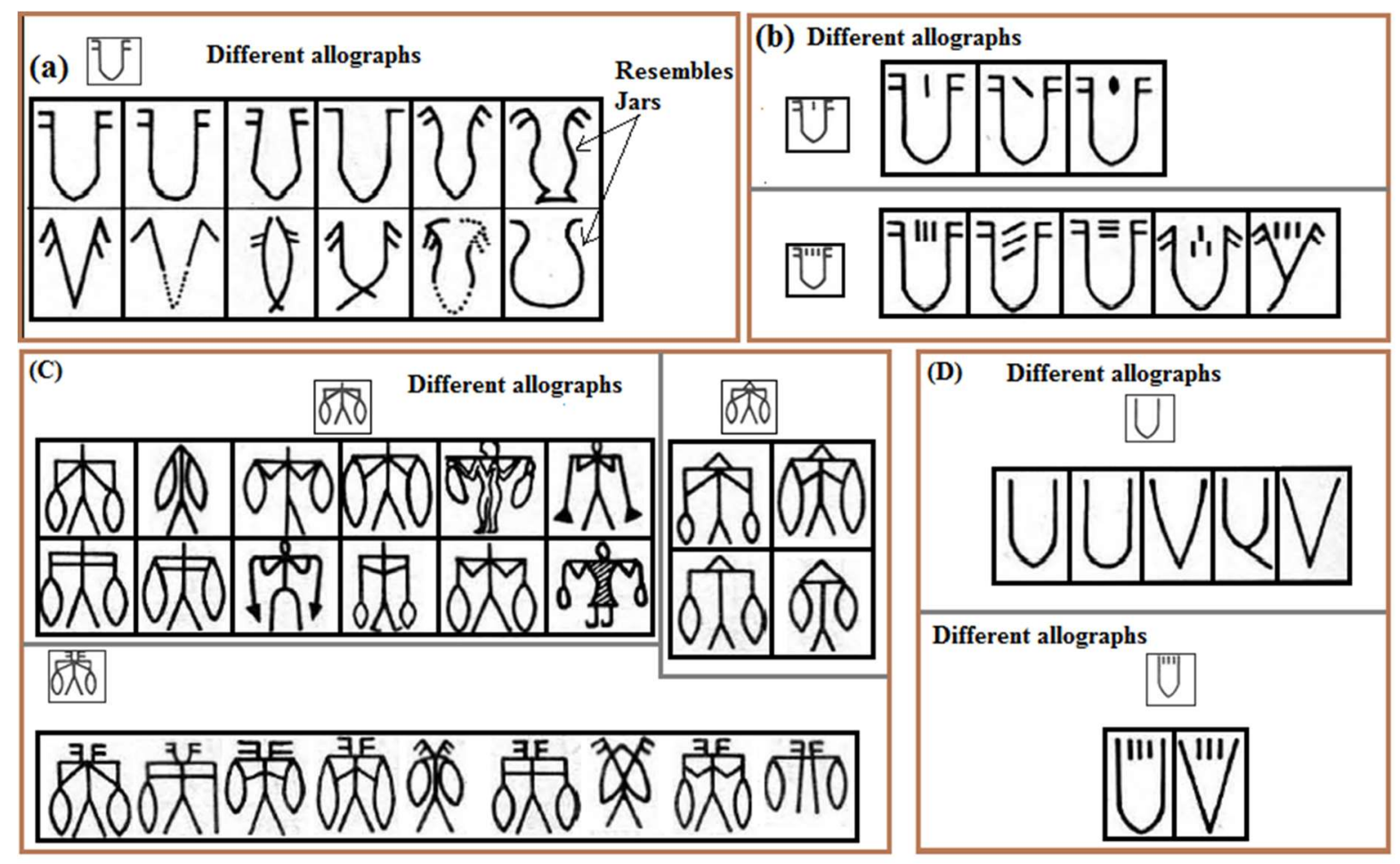

Moreover, analysing the lexicons of various Indic languages of Northern India, it becomes clear that the word "drona" was used in various regional languages with the same meaning. For example, in Pāli, Prākrit, West Pahārīi, Kāśmīrī, Kumauṇī, Assamese, Bengali, Bhojpurī, Awadhī, Hindi, Marāṭhī and Sinhalese, "drona" and its derived terms such as "dona", "duni" etc. meant either a "trough" or a "grain measure" or both (Turner, 1999). Looking at the weight-based metrological units, we find a very similar situation. The weight-based metrological units frequently mentioned in Arthaśāstra, are "dhāraṇa", "pala" (10 dhāraṇa), "tulā" (100 pala), and "bhāra" (20 tulā). In Sanskrit, "dhāraṇa" means "holding, bearing, carrying" etc., "tulā" means a "a balance, weight, to hold in a balance, to weigh, compare" etc., "bhāra" means "a burden, load, weight, a particular weight, a pole or yoke for carrying burdens" etc. (Monier-Williams, 1872). Similarly in Tamil,"tulā", "tulāi", "tulām" etc. means "balance" or "steelyard", or some market weight (Tamil lexicon, 1924-1936).

Besides the spatially widespread usage of the metrological terms like "drona", "tulā" etc., their incredible time-travel across thousands of years would also help us to extrapolate whether they found use in the Indus era as well. Among the volumetric standards mentioned above, "drona" was one of the most versatile ones, used to measure a wide range of substances. In Vyasa's Mahābhārata, a subsection named "Vrīhi-Draunika" tells the tale of a virtuous man "Mudgala" who lived on one "drona" measure of grains for a fortnight (Sarma, 2008). The terms "droṇa" and "āḍhaka" continued to be the main volume-based metrological standards across Northern India. As described in the Paharpur copper plate inscription of Gupta period (AD 479), the units "droṇavāpa" and "ạḍhavāpa" were used to measure amount of land-areas which were required to sow "Drona" and "Āḍhaka" measure of seed-grains (Pruthi, 2004). Moreover, in Līlāvatī of Bhāskarāchārya (Taylor, 1816), the relationship described between the grain measures āọhaka, "droṇa", "khārika" and "prastha" remained the same as mentioned in Arthaśāstra, although it was composed almost 1500 years earlier. Moreover the agro-metrological unit "droṇavāpa", was transformed into the colloquial term "don", which was used in different parts of undivided India. Surprisingly, it is used in Bangladesh till date, even though its values in different regions differ largely from the value of the ancient unit (Taylor, 1816). In the year 2019, news about the plight of farmers in Bangladesh (see Supplementary- 
file-1) used "don" as the measure of field, along with other modern Metric units. Considering that the term "drona" could sustain its meaning for more than 3000 years since the era of Rigveda, despite the influences of various competitive metrological standards including the current international standards embraced by the governments of India and Bangladesh, it would not be illogical to claim that the jar-like metrological units of Indus inscriptions ( ' ' ' '"'F, $U,|'|$, etc.) were used throughout $2600-1900 \mathrm{BC}$ ( $1900 \mathrm{BC}$ is just 800 years before the latest dating of Rigveda's composition (Flood, 1996:27-39)), and that they represented either different denominations of these "drona", "kumbha" or "kuduba" standards, or similar volumetric standards etymologically rooted in the words used for "jar", "pot", "trough", "pitcher", "vessel" etc. Similarly, if the terms "tulā", "bhāra" etc. get associated with weight-based metrological system even now in modern India, both in its northern and southern parts, then the "load-bearer" graphemes ( with the terms like tulā", "bhāra" or "dhāraṇa", had arguably signified weight-based metrology even in the Indus era. Interestingly, very similar usages are found in Linear-B inscriptions, where different shapes of vessel-ideograms represented different volumetric standards for dry and liquid measures along with the measured commodity-types, and such vessel-ideograms also had fractions written<smiles>C1CC2CCC2C1</smiles> \\ etc.) Similarly, the}

inside and next to them (compare the Indus semasiograms

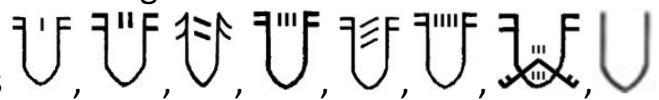
Linear B ideogram $\Delta$ और "highest unit of weight" used by the Minoans and Mycenaeans, (compare the Indus script scheme of

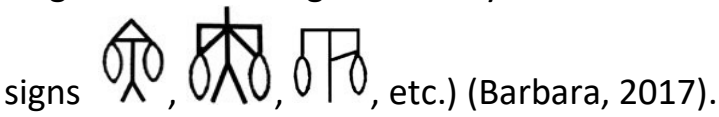

Thus, the graphemes chosen for Indus PF1 and MET-signs were evidently related to the ancient metrological-vocabulary. But, looking at the PF1-signs' phrase-level usages, it becomes clear that unlike the MET-signs, they were not directly used to quantify any lexeme sign. Then what was the PF1-signs' role in so many taxation/trade-control-centric Indus inscriptions? The answer lies in the close relationship between metrological standards and revenue standards maintained in ancient urban civilizations, and as before, the historical evidences found from ancient texts of Egypt, Mesopotamia, and India help us find the answer. As explained in Arthaśāstra, in the ancient Indian economy where the concept of money was not yet perfected, to automate revenue collection methods of different commodities, and to avoid repetitive calculation of taxes, the popular metrological units were manufactured in four standard versions. The "āyamāna-drona" was the volumetric revenue standard for measuring royal income and it was supposed to hold 200 palas in the grains of másha (Shamasastry, 1929, Kautilya: 51-185). The other drona-standards were 'Trademeasure or public-droṇa', 'Payment-measure' ("bhājanīya") and 'Palace-measure' or "antahpurabhājanīya", which were respectively $93.75 \%, 87.5 \%$, and $81.25 \%$ of the capacity of "āyamāna-drona". Similarly, "different weights were used for automatic collection of the transaction tax" (Rangarajan, 1992:901), due to which, 4 different versions of "Tulā" and "Pala" weights were used for royal revenue, trade, payment and palace measures. Fascinatingly, even in Mesopotamian documents such different versions of the revenue-based metrological standards are found. For example, the Mesopotamian capacity unit "šutu" had different standards such as "tax šutu", "ration šutu","šutu of the palace" etc., and the "tax-šutu" was standardized as 1.5 times of the "ration-šutu" (Powel, 1990). Just like these different versions of "drona" and "šutu" measurements, the Egyptian cubit also had a royal version (c. $523.5 \mathrm{~mm}$ ) and an ordinary version (c. $500 \mathrm{~mm}$ ). The "Pharaoh bought 
goods using the royal cubit and, subsequently sold them using the common cubit", the difference between the measures being equivalent to the "tax paid to the Pharaoh" (Williams, 2014:7).

Based on the evidence above, I propose that the PF1-signs denoted the metrological mode of collecting particular taxes, whose collection would get endorsed by the inscriptions of corresponding seals/tablets. Since the metrological-mode was directly mapped to different revenue-based standards, it must have been considered as an important piece of information for endorsing the taxpayment. Apart from this, another reason of mentioning metrological modes in tax-calculation could be that the tax-rates for the same tax were different, depending on the metrological mode used in the process. For example, as mentioned in Arthaśāstra, the rate of the tax called "Vyājī" was one sixteenth of the quantity of the commodity when measured by cubical units, one twentieth of the commodity when weighed, and one eleventh of the commodities when numerically counted (Sarkar, 2003:96).

Possibly because of all these reasons, the people of IVC correlated the tax-collectors with the metrological modes and tools used by them, and possibly even used the metrological tools as metonyms for the tax-collectors. As documented in Kurudhamma Jātaka, the revenue collector was named "dōṇamapāko Mahāmātta", an official "so designated presumably because he supervised the grain-measurement by the cubic measure dōṇā (drōṇā)" (Prasad, 1987:40-41). Jātaka stories mention another official "rajjugāhaka-Amācca", who measured the fields with "rajju" (rope) and "danḍa" (pole/rod), literally "rajjam danḍake bandhitvā", while riding a chariot (Prasad, 1987). Furthermore, in Arthaśāstra, Kauțilya talks about different administrative centres called "saṃgrahaṇa", "kārvațika", "droṇamukha" and "sthānīya", which were supposed to comprise 10, 200,400 , and 800 villages respectively. This study claims that, the derivation of the administrative "dronamukha" from the metrological "drona" quite obviously indicates that the word was rooted in metrology and revenue collection, just as the word for the administrative centre "samgrahana" etymologically derived from the Sanskrit word "saṃraha", literally signified "to gather together, assemble, collect" etc. (Monier-Williams, 1872). Intriguingly, Egyptian, Mesopotamian and Assyrian cultures too evince such parallel metonymic metrology. In Mesopotamia, the metrological word "sūtu" or "šūtu", which primarily meant "a vessel", "a measuring vessel of a standard capacity and its volume", "a measure of area based on the quantity of grain necessary for seeding", also meant "(a tax), rent for a field or orchard paid in kind" (Reiner, 1984). Moreover, the word "šutummu" signifies "a storehouse", while the word "šatammu", which is "clearly connected to the storehouse", represented certain revenue collecting personnel in Babylonian and Assyrian contexts (Johns, 1999). Although Assyriologists do not usually connect the words "šutummu" and "šatammu" to "šutu" yet, I suggest a semantic association between them comparable to that between "drona", "Droṇamāpaka" and "Droṇamukha". In ancient Egypt too tax-collectors were named after metrological equipment. For example, in a "tax-assessor's journal of the late Middle Kingdom", certain surveyors of the field are called "rope-bearer" and "rope stretcher" (García, 2013), which is a direct parallel to the above-mentioned Indian term "Rajju-gāhaka".

All these evidences reinforce my contention that the PF1-signs denoted names of broad tax categories, named after the metrological modes used to collect them. While vessel-like $\mathcal{V}$ denoted the most popular taxation method collected using volumetric modes, "load-bearer" $8 / 8$ signified weight-based taxes, the composite PF1-sign $8 \wedge$ possibly denoted taxes that could be collected by using both weight-based and volume-based metrology. 


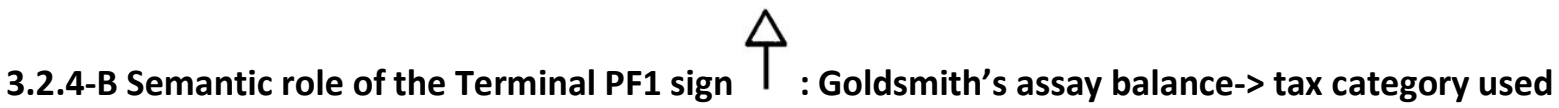
for taxing precious stones, metals, metal-smithy, gold-smithy, lapidary work, shell-work, and related trade and manufacturing permits

If the broad semantic scope of the PF1 signs are related to names of metrological standards and

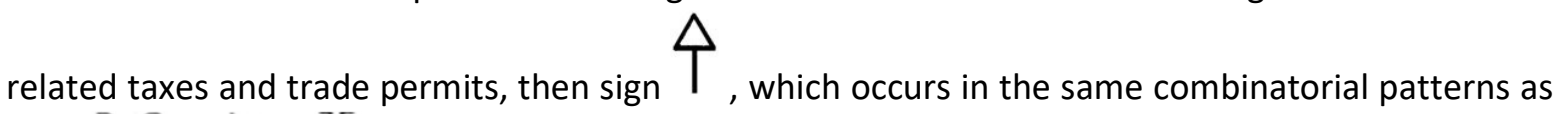
signs $\mathcal{F}, 8 \wedge 0,8 \wedge 0$ etc., must also have had similar semantic functionality. For, among the 311

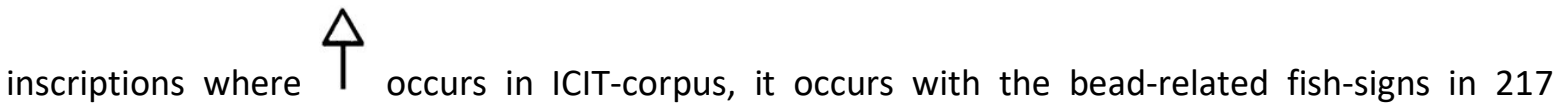
inscriptions, i.e. in $70 \%$ instances. In many of these instances, it also occurs with the gold-smithy related Crucible-Blowpipe signs. There are only 76 inscriptions in ICIT where the 1 sign occurs without fish-signs and crucible-blowpipe signs. In those inscriptions too it occurs mostly with semasiograms -E (15 times), $\bigwedge_{\text {(7 times), }} \overbrace{\text { (7 times), }}$ (5 times) - which themselves

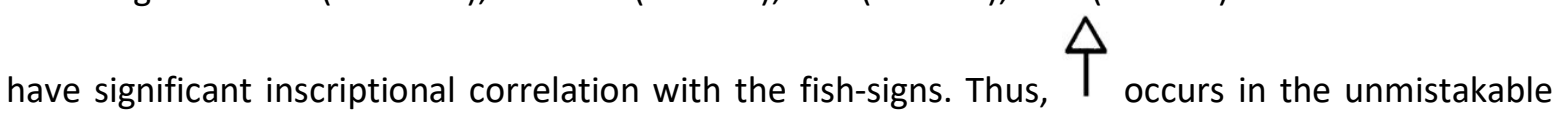
contexts of precious commodities. Now, it is a well-known fact that precious commodities are weighed using a different range of minute weights and are taxed in a different rate than other commodities. Such small weights are generally found in gold-smith's shop, and are found very often in Indus valley cities (Kenoyer, 2010), near gates of fortified towns, and near workshops where beadmaking, and metal-smithy happened (Mackay, 1943). Now, this study proposes that sign had symbolized assay balances or goldsmith's balances, since such balances usually had an arrow-like pointer that is used to minutely indicate the equality of weight in both the scale-pans (see Fig. 2c). Interestingly, there is direct archaeological evidence of such weight balances, endowed with 'matched scale pans' made of 'copper/bronze and occasionally of terracotta', two sets of which were exhumed in 1996 in the course of conservation work on Mound F at Harappa (Kenoyer, 2010). One of these scale pans was around $6 \mathrm{~cm}$ in diameter, which contained three holes for hanging the plate evenly. This scale was evidently an analytical balance or assay balance, suitable for weighing only very small size weights. Intriguingly, a bronze cross-beam, a hook and chain, and a broken arrowshaped pointer were also found along with these scale pans. Now, this arrow-shaped pointer must have been used for precisely indicating the equality of weights of the scale pans (in a private email communication in 2015, in reply to my query, Jonathan M Kenoyer had hazarded the same use of this arrow pointer). Thus, archaeological evidence supports that assay-balances of IVC had used arrow-like pointers. Hence it is quite possible that such distinctive arrow-like pointers of assaybalances were used to symbolically represent assay-balances in Indus-Inscriptions. I have strong linguistic evidence to support this conjecture, as ancient Indic words for a special type of arrow were also used to refer to assay balances. For example, a Telugu dictionary (Brown, 1903) contains the word 'nārāchamu' which means "an iron arrow", and the related word "nārāchi" means "an instrument to cut gold" and also "the balance used by a goldsmith". Though this Telugu dictionary refers to this as a Sanskrit word borrowed in Telugu, I am not sure whether this word originally had Indo-Aryan or Dravidian etymology. Another Tamil dictionary (Tamil Lexicon) records 'nārāchamu' as a type of iron arrow. In Sanskrit, both "nārācī" and "nārācikā" mean "goldsmith's scales", although "nārācaḥ" means arrow (Monier-Williams, 1872). The authoritative Bengali dictionary of Haricharan 
Bandyapadhyay (1933-1946/1966) provided the very etymology of "nārāchi", which records (in Bengali) that 'nārāch' means a specific type of iron arrow whose edges are sharp and straight, whereas 'nārāchikā' or 'nārācī' means a goldsmith's balance that looks like a 'nārāc' (p. 1194). Similarly, the Sanskrit words "eșaṇi" and "eșaṇikā" mean goldsmith's scales, whereas eșana signifies an iron arrow (Haughton, 1987; Monier-Williams, 1872). Interestingly, even in Arthaśāstra (Shamasastry, 1929 p. 111) "nārāca" is mentioned as a type of arrow, proving the ancient use of the word. Thus, iconicity and script-internal, archaeological and linguistic evidence confirm the decipherment of 4 . Plausibly, the semasiogram (found only in 5 inscriptions of ICIT), where a scale-balance with an arrow-pointer on top is schematically represented, was a semasiogram related to $\triangle$. A corroborating evidence of their relation comes from Seal \#H-103 of Harappa (see Fig. 10c), where three Indus script phrases (

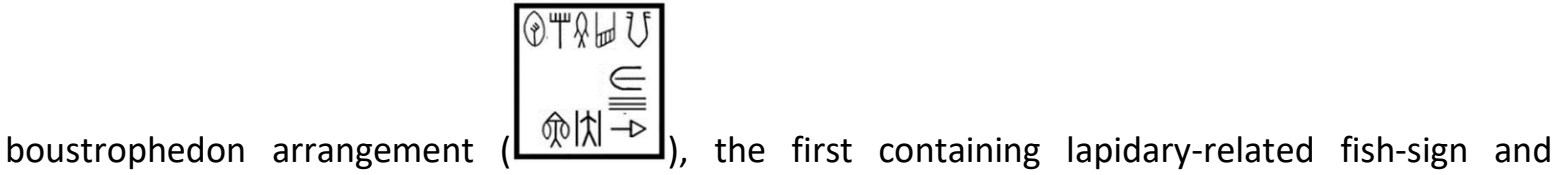
terminating with a volumetric-taxation sign, the second containing precious-metal related crucibleblowpipe sign and terminating with the precious-commodity-taxation related arrow-sign, and the third containing this scale-pan-with-arrow-pointer semasiogram Seal M-1276 of Mohenjo-daro, 躭 occurs with the fish-sign (lapidary-related) like sign $\uparrow$.

\subsection{Explanation of the general semantic scope of Indus-Inscriptions:}

The subject matter of Indus inscriptions mostly revolved around recording the collection of certain standardized taxes, tithes and licensing-fees to control the production and trade of various merchandises in the commercially thriving fortified settlements of IVC, and issuing commercial and trade permits to allow Indus traders to operate in the regulated market areas. The seal-impressions marked on packed bales of goods endorsed that the applicable tax/tithe for those goods were already paid, and the merchandises could be transported to their destinations, just as the customs and excise departments in our modern world stamp commodities after their appropriate taxes are paid. The bas-relief tablets and certain inscribed seals might have been used as "commercial licence" or "trade licence" documents so that the owners of those seals and tablets could continue with their commercial activities. These claims made in this paper are substantiated through the following archaeological and script-internal evidences.

According to Kenoyer (2010:109), the massive mud brick walls surrounding most large IVC settlements had served primarily for control of trade access to the cities. He also found that the devices for control of trade, such as seals and weights, were often "concentrated near gateways and in craft areas located near the gateways or along major streets" (Kenoyer, 2010:109). Analysing the field works of other archaeologists, Wells (2011:87) and Parpola (1994:114) discovered the distribution of seals in several contexts to be highly correlated with the distribution of Indus weights in Harappa and Mohenjo-daro. For, the seals and weights were found together in same houses of Mohenjo-daro and sometimes even in the same rooms of those houses. In the excavation reports of Gola Dhoro, a small fortified Indus settlement thriving in craft production of "shell, semi precious 
stone, faience and copper", archaeolgist Bhan (2011:340) expressed wonderment that in such a diminutive settlement "the site revealed five inscribed seals", and surmised that these seals were "used in trade and transitions by the Indus people". These scholarly judgements and many more similar evidence found in other excavation sites make it clear that the usage of the seals had very strong association with (i) the fortified city gates of Indus settlements; (ii) the standardized Indus weights; and (iii) the activites performed in various craft making areas and workshops. Now, both the fortified city walls and the standardized Indus weights were associated with trade regulations and tax/tithe collections. As Kenoyer corroborates, "recent excavations at Harappa reveal that the highest concentration of weights is located in association with gateway areas or in craft production areas, where goods entering the city may have been weighed and taxed". Besides, "many of the smaller sites such as Allahdino, have only a single set of weights in the middle range of values, while only the largest sites such as Mohenjo-daro and Harappa have one or two extremely large weights" (2010:117). His explanation of this is that tax collectors or village elders in the smaller settlements "would have needed only one or two sets of weights to collect tribute in special commodities and produce", whereas heavier sets of weights were needed in the larger urban centres, being "well suited for weighing tribute coming from all of the surrounding villages and towns" (Kenoyer, 1998:99). So, Kenoyer thinks the distributional characteristics of the standardized Indus weights indicate their use for tax and tithe collection, not for day-to-day barter activities. Since the massive city walls found in Indus settlements lacked defensive planning, they were "intended to control the trade and commerce which was the life blood" for the Indus cities. As documented by Mclntosh (2008:223), several Indus settlements (Harappa, Mohenjo-daro, Dholavira, Kuntasi, Chanhu-daro, Lothal, Kalibangan, Banawali, etc.) were fortified partially or wholly by brick walls with imposing gateways, where "[s]ide chambers often flanked the gateway, probably accommodating gatekeepers, who could monitor the flow of people into and out of the city" and could "collect taxes or customs dues on goods being brought into or out of the settlement". Now, even though written in 4th century BCE, Arthaśāstra has recorded various economic traditions of ancient India, which were practised much earlier than the Mauryan period. In some of its passages that describe the responsibilities of the "chief collector of customs and octroi", we find suggestions about i) setting up custom houses near the main gates of the fortified city facing east or north; ii) stationing four or five customs collectors in each post; iii) checking everyone entering the city; iv) allowing dutiable goods "to be sold only after they had been weighed, measured or counted [and duty paid accordingly]"; and v) keeping records of the merchants' names, the quantity of their merchandise, the place of the issue of their identity pass, and the place where the goods were sealed etc. (Rangarajan, 1992:406). These passages provide direct historical evidences about the nature of the customs centres of ancient India, which were predominantly located near the gateways of the fortified cities, and were equipped with seals and standardized weights, just like the customs centres of ancient IVC. In my opinion, the customs centres of IVC were equipped with other metrological equipment too, such as earthen vessels and reed baskets of standardized volumes, which because of their perishable nature could not be discovered as part of the excavations, unlike the stone weights and seals that have defied the ravages of time to inform us about their rich lineage. In this context, Rao's (1979, Vol. 1) comments about the "warehouse" found at the port town of Lothal, where many clay sealings bearing multiple seal impressions were found, is quite relevant. Rao (1979 p. 21) says, the discovery of these terracotta sealings bearing impressions of packing materials establish that Indus seals were used in export-import trade for sealing cargo. Rao $(1979$, p. 113) further adds that the podiums at Lothal remind him of podiums described in Tamil epics like Pattinappalai and Silappadhikaram, referring to the sealing of goods with the Tiger emblem of the Chola kings after payment of customs duty and before these goods passed on to the warehouses of the merchants, allegedly for export. "Two thousand years before Kaveripattinam came into existence Lothal folk had also built a 
warehouse where, perhaps, the incoming and outgoing cargo was sealed after payment of customs duties". Now, since the archaeological evidence strongly indicates that inscribed seals and standardized weights were functionally correlated, and they were often found near the customs posts situated closed to city gates, we can surely conclude that such seal-inscriptions were predesigned messages that could record the collection and payment of various toll and custom duties.

While certain stamp seals were predictably used to collect customs and toll type dues, the seals that are found in the workshops of lapidary-craft, metal-working, shell-cutting etc. (Kenoyer, 2010; Mackay, 1943), were possibly used to collect taxes on the artefacts produced in such workshops and also the sales of their products. Possibly tax-collectors employed by merchant-guilds and/or the fortified settlement's controlling authorities, were posted in such workshop areas, who carried these seals and endorsed the merchandise after collecting predefined taxes.

On the other hand, the inscribed bas-relief tablets might have been used as commercial permits and trade licenses, for which their owners had to pay fixed amounts. As observed by Possehl (2002:131), unlike the typical stamp seals which were used to make a lot of seal impressions, certain other seals were worn only at edges, with their interior carvings retaining "fresh, crisp" lines, which suggest that these seals "may have been used primarily for visual identification. The seal itself, not the impression, was shown. It identified, or gave some form of legitimacy, to the bearer". In my opinion, Possehl's inference accounts for the unusually high concentration of Indus seals found near the craft areas and workshops of lapidary-craft, shell-cutting, metal-smithy, etc., since those seals and tablets visually identified their owners as authorized practitioners of specific commercial activities.

Certain commercial activities of IVC must have involved different departments of "stateappointed", "city-appointed" or "guild-appointed" officials who collected different type of taxes for the same commodity. As recorded by Frenez and Tosi (2005) and Parpola (2007), among the 93 sealings/tags found from the burnt-down "warehouse" of Lothal, 63 tags contained single sealimpressions and 67 tags contained multiple impressions of different seals, comprising a total 130 seal-impressions, where the seals contained unicorn, bull and elephant iconographies. As per Parpola (1994:113), these kinds of tags were generally "attached to bales of goods, for their reverse sides usually show traces of packing materials such as woven cloth or reed matting". In my opinion, this evidence suggests that, certain packed commodities were taxed in several different ways by differently authorized officials, and each official had endorsed the payment of the respective taxes based on the content of the packaged good, using a separate seal-impression. I compare this situation to a cargo container of modern times that moves through different parts of a country, pays different types of taxes in different check-posts, and thus gets stamped and endorsed by different authorities.

Finally, if the Indus inscriptions were used for taxation and trade-control, they would predictably have been used in a standardized manner in different Indus locations. The existence of identical and near-identical inscriptions engraved on seals, sealings and tablets found in very distant Indus locations strongly supports this hypothesis. As depicted in Fig. 10 below, in certain instances, different seals and tablets used in Harappa, Mohenjo-daro and Lothal were engraved with identical inscriptions, while Harappa was almost 600 kilometres away from Mohenjo-daro and around 900 kilometres away from Lothal. Thus even though scholars have considerable doubts regarding whether there was some centralized "state" operating in ancient IVC, this study can at least argue that there must have been certain organized elite classes, most possibly "merchant clans", who 
maintained systems of standardized taxation and equivalencies so that the widespread barter-based trade network of IVC, crucial for the manufacturing of various complex commodities, could smoothly operate (Ahmed, 2014:141).

Figure 10. Examples of certain identical inscriptions found in distant Indus locations

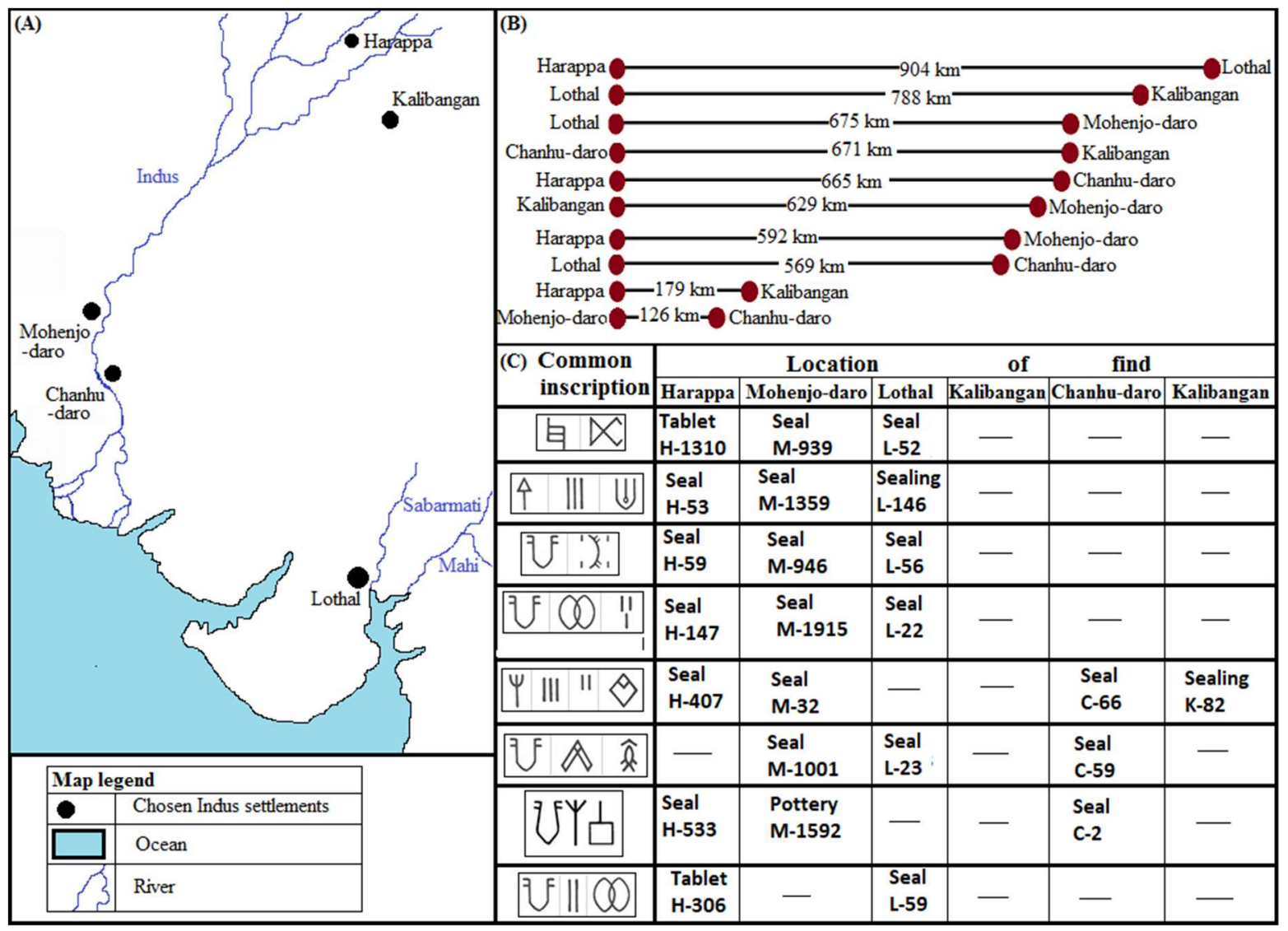

Possibly, if a commodity was endorsed (regarding some tax-payment) by a stamp-seal impression issued by the authorities in ancient Lothal, it had to be accepted by the respective authorities operating in Harappa and Mohenjo-daro as well, and vice versa, to avoid repeated taxpayments by merchants. Eminent historians contend that these merchant clans were most possibly responsible for producing the "large scale public goods" such as building the city roads, water reservoirs, sanitation systems etc. in their local operating regions (Ahmed, 2014). I think that these "trade guilds" or "merchant clans" must have collected different types of taxes to bear the expenditure of these public welfare activities. Thus, the way modern governments take toll taxes for using certain highways or bridges, these merchant clans operating in specific cities might have imposed taxes on traders for selling their goods inside the regulated markets in their fortified cities. Frenez (2018) makes a similar observation that the standardized seals were used "within a hierarchically regulated structure of officially established and liaising socio-economical-and possiblypolitical" power structures, in the "highly unbalanced oligopoly" that prevailed in IVC for more than six centuries. Thus the Indus seals and tablets, which were miniature portable and durable objects, were crucial machineries in the taxation and trade-control systems exercised across the one million square kilometres of Indus valley civilization. Now, since more than $85 \%$ of the Indus-Inscriptions 
are found from these miniature seals and tablets, they were undoubtedly used mostly to encode information needed for Tax-stamps and commercial permits.

\subsection{Specific inscription segments encoding specific types of information through specific classes of signs:}

Section-3.1 has already given a brief overview regarding the formulaic structures of IndusInscriptions, and certain broad functional categories of Indus script signs. Now, the formulaic Indus-Inscriptions can be structurally classified into two broad categories:

i) non-composite inscriptions

ii) composite inscriptions

The composite inscriptions are those, which contain certain conjunctive-signs (

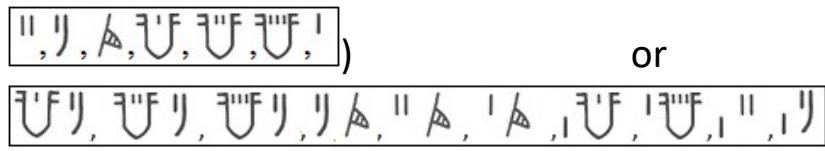
conjunctive phrases complete inscriptional units to connect their meanings (in subordinating and coordinating ways), thus forming longer composite messages (see Ansumali-Mukhopadhyay, 2019). The non-composite inscriptions do not contain these connective signs or phrases. Usually, a signsequence, that occurs following the connective sign in a composite inscription, also occurs independently as a complete inscription of a seal, sealing or a tablet. For example, in case of the 88 composite inscriptions listed in Fig. 11, almost all of their post-connective constituents (marked as $\mathrm{Y}$ ) are semantically complete messages that occurred independently as non-composite inscriptions in other objects (Ansumali-Mukhopadhyay, 2019). For example, the non-composite

inscription incised tablets of Harappa, and 1 stamp seal of Mohenjo-daro, whereas it occurs as the post-

connective constituent in inscriptions

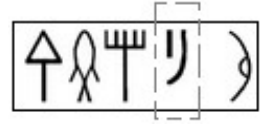

(Seal\#H-1669 of Harappa) and

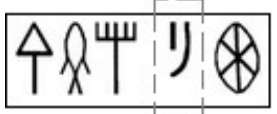

(Seal\#M-163) of Mohenjo-daro (the connective sign Is marked using dotted lines). Below, in Section-3.4.1 I shall discuss how different parts of these noncomposite Indus-Inscriptions had encoded information regarding i) taxed or licensed commodity types; ii) fixed rates of taxes; iii) metrological modes of tax-payment iv) the commodity used for paying the tax, etc. Next, in Section-3.4.2 I shall explain the semantics of the composite Indus-Inscriptions and the meanings conveyed by certain signs that very often occur in the pre-connective positions. 
Figure-11 Certain composite inscription of Indus script

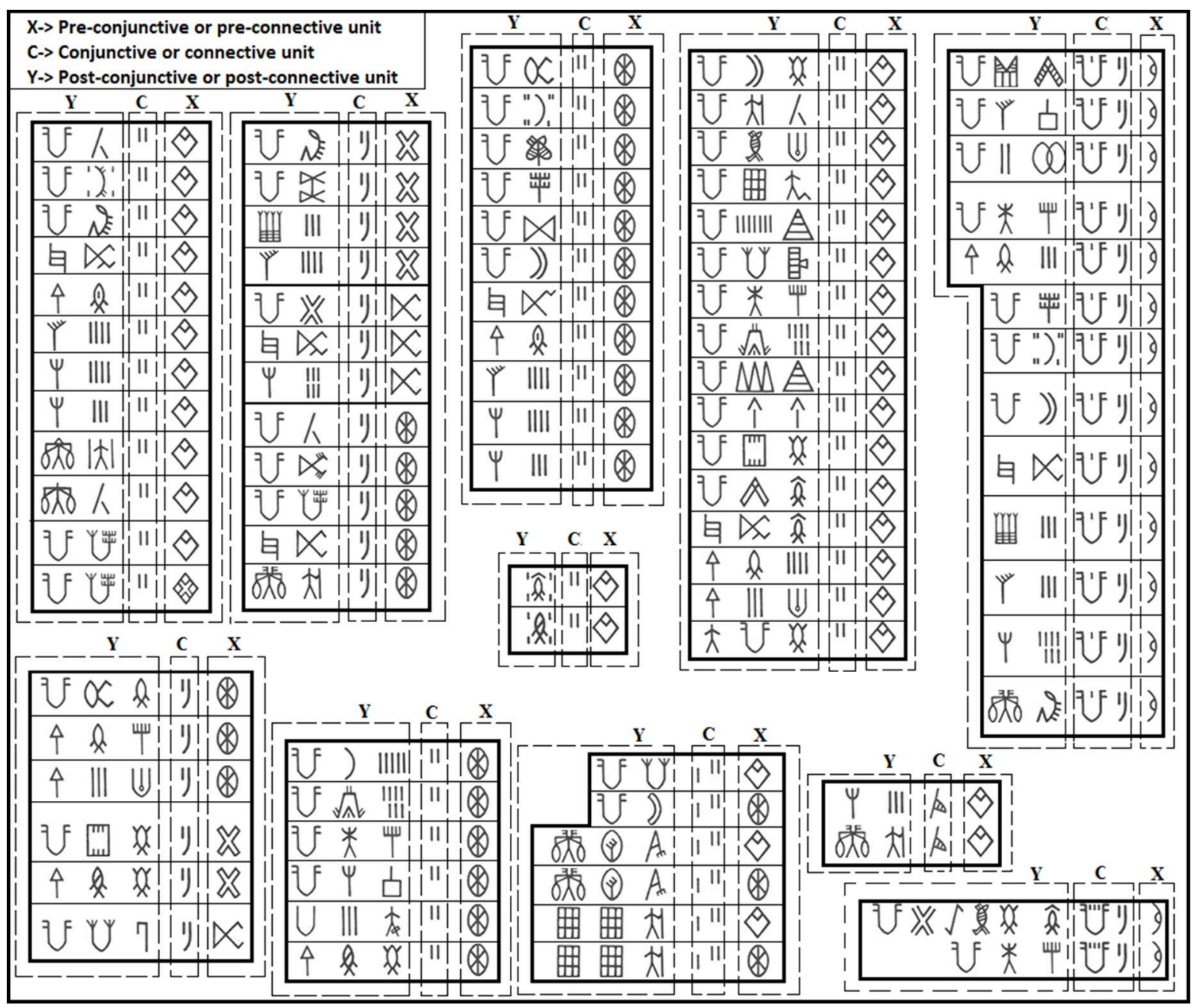

\subsubsection{Non-composite inscriptions}

The non-composite inscriptions are composed of the following patterns and their combinations.

\subsection{1-A Pattern-1: Series of taxed and licensed commodity-types and/or commercial activity-types followed by the metrological category of taxation}

In Section-3.2, I have already established that the crucible-blowpipe semasiograms (

U. (U) signified gold-smithy, gold, precious metals, metal-smithy etc.; the fish-signs ( $\hat{x}$, , $\{$, etc.) denoted beads, gem-stones, lapidary craft, and bead-related metrological 


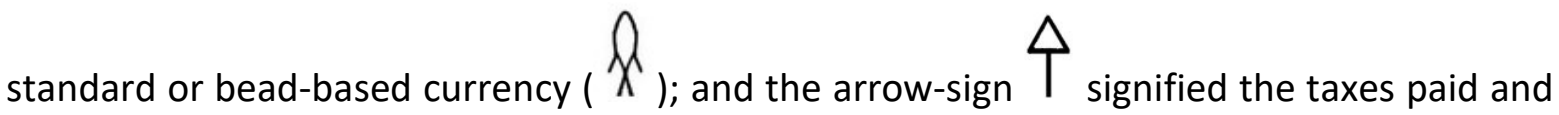
trade-licences issued for precious commodities. These decipherments help us to visualize how majority of the non-composite Indus-Inscriptions had encoded certain taxed/licensed commodity-types and commercial activity types, along with the metrological category of taxation. For example, as shown in Fig. 12a, the crucible-blowpipe followed by the threestroke numeral (possibly signifying three metals, i.e. gold, silver, and copper) occurs with the terminal-sign $\widehat{S}$ to signify metal-smithy related commercial licenses and tax -stamps.

Figure-12 Non-composite Indus inscriptions containing a series of taxed commodity-types followed by the terminal signs signifying the metrological tax-categories
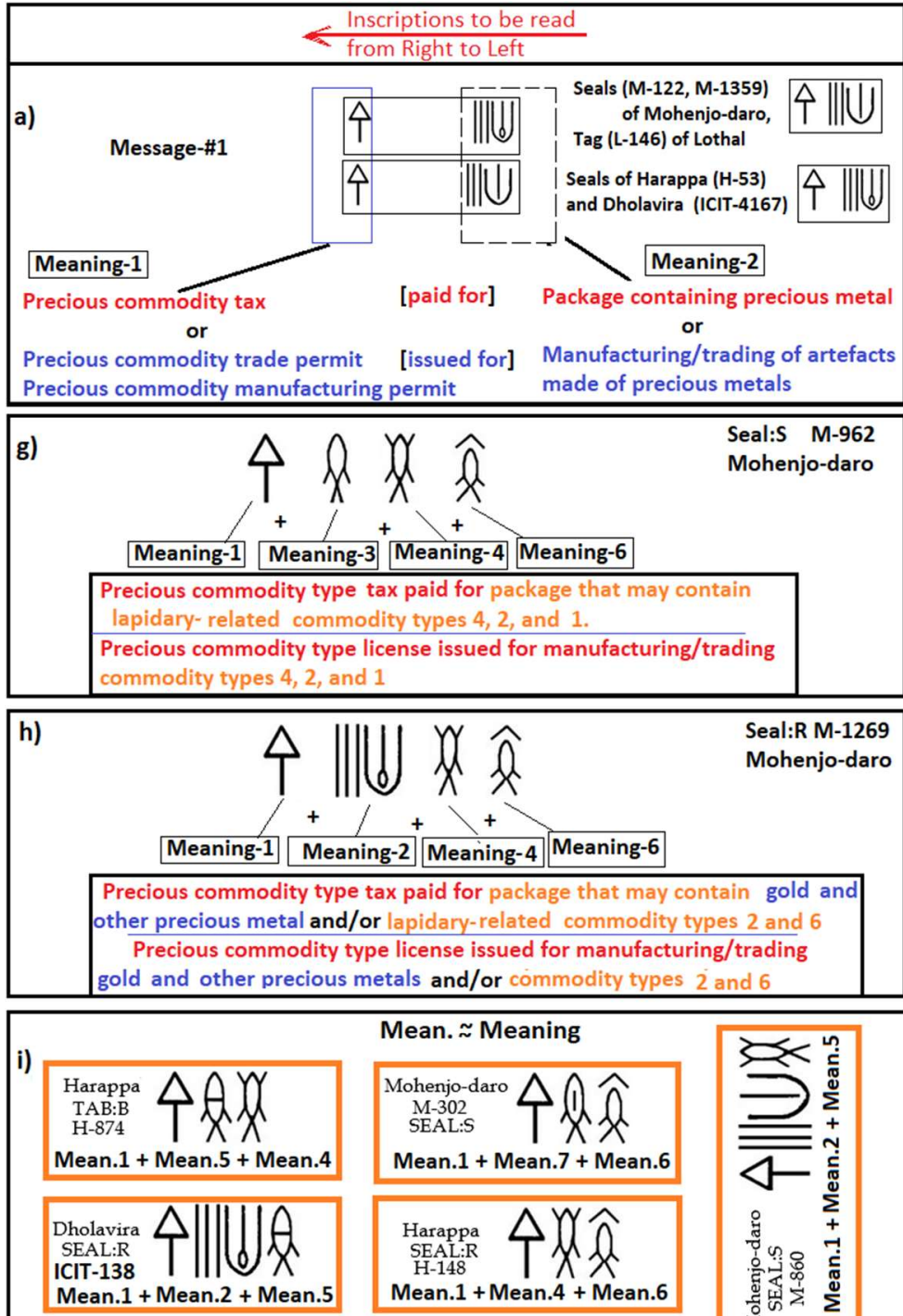

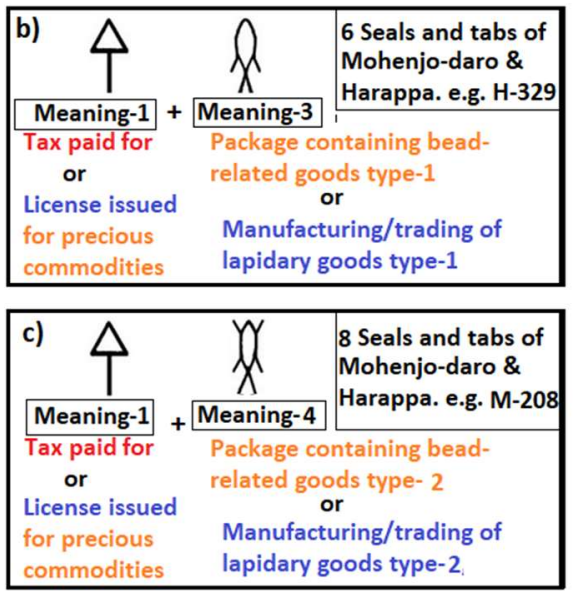

\begin{tabular}{|c|c|c|}
\hline d) & & $\begin{array}{l}3 \text { Seals and tabs of } \\
\text { Mohenjo-daro \& }\end{array}$ \\
\hline Meaning-1 & Meaning-5 & \\
\hline $\begin{array}{l}\text { Tax paid for } \\
\text { or } \\
\text { License issued } \\
\text { for precious } \\
\text { commodities }\end{array}$ & \multicolumn{2}{|c|}{$\begin{array}{l}\text { Package containing bead- } \\
\text { related goods type- } 3 \\
\text { or } \\
\text { Manufacturing/trading of } \\
\text { lapidary goods type- } 3\end{array}$} \\
\hline
\end{tabular}

\begin{tabular}{|c|c|c|c|}
\hline e) & $\hat{x}$ & \multicolumn{2}{|c|}{$\begin{array}{l}1 \text { seal, } 2 \text { tablets, one } \\
\text { pottery shard from } \\
\text { Dholavira, Harappa } \\
\text { and Mohenjo-daro }\end{array}$} \\
\hline $\begin{array}{l}\text { Tax paid for } \\
\quad \text { or } \\
\text { License issued } \\
\text { for precious } \\
\text { commodities }\end{array}$ & $\begin{array}{l}\text { Package cc } \\
\text { related go } \\
\text { Manufact } \\
\text { lapidary }\end{array}$ & $\begin{array}{l}\text { ntaining bead- } \\
\text { ds type- } 4 \\
\text { r } \\
\text { uring/trading } \\
\text { oods type- } 4\end{array}$ & $\begin{array}{l}\text { e.g. } \\
\text { M-487 }\end{array}$ \\
\hline
\end{tabular}

\begin{tabular}{|ll|}
\hline f) & K-32, Seal Kalibangan \\
\hline $\begin{array}{c}\text { Meaning-1 } \\
\text { or paid for } \\
\text { or }\end{array}$ & $\begin{array}{l}\text { Package containing bead- } \\
\text { Lelated goods type- } 5 \\
\text { or }\end{array}$ \\
$\begin{array}{l}\text { Mense issued } \\
\text { ror precious } \\
\text { commodities }\end{array}$ & $\begin{array}{l}\text { Manufacturing/trading of } \\
\text { lapidary goods type- } 5\end{array}$ \\
\hline
\end{tabular}


Similarly, in Fig. 12b-f, five different fish-like semasiograms, $\mathrm{x}, \mathrm{x}, \mathrm{x}, \hat{\mathrm{x}}, \mathrm{x}$, which must have expressed different meanings related to beads, gem-stones, and lapidary-craft,

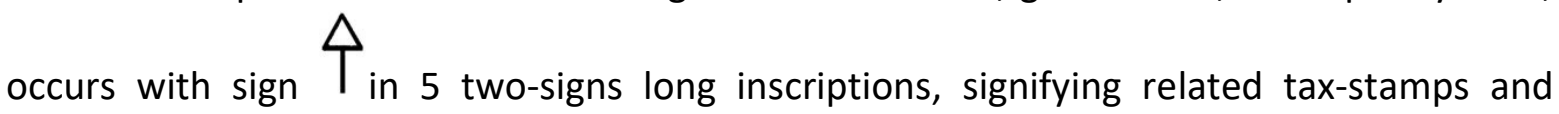
commercial licenses. Now, in the seal-inscription shown in Fig. 12g, three of these bead and gem related signs co-occur to signify a tax-stamp/trade-permit that deals with multiple types of bead-related commodities and commercial activities. Similarly, in Fig. $12 \mathrm{~h}$, the bead-

related signs co-occur with the gold-smithy and precious metal related phrase 110 , to signify the message of a tax-stamp/commercial-license, which deals with both bead-making and metal-smithy. Many other such combinations are shown in Fig. 12i. In each of these inscriptions, as expected, the precious-commodity taxation/licensing sign $\mathrm{T}_{\text {occurs at the }}$ phrase-final or terminal position.

\subsection{1-B Pattern-2: Fixed set of numerical-signs signifying fixed tax-rates precede semasiograms that conveyed certain commodity-specific metrological standards}

Looking at the Indus inscriptions collated in Fig. 13a, it becomes clear that certain strokesigns, which are identified as numerical signs or NUM-signs by Ansumali-Mukhopadhyay (2019), occur in fixed patterns before the bead-related sign $\mathcal{X}$. Similarly, in the inscriptions of Fig. 13b, sign $\mathcal{X}$ occurs after a fixed set of numerical signs, followed by the terminal semasiograms that signified different metrological tax-categories. In Fig. 13c, we can see how the PF1 semasiogram category 818 , and volume-based tax category $J$, possibly to signify some metrological standard of weight-volume equivalency) occurs preceded by certain fixed set of numeral-signs, in several seals, sealings, and tablets. Moreover, as shown in Fig. $14 \mathrm{~d}$, a fixed set of numerical signs occur before certain phytomorphic semasiograms $(\Psi, \Psi$, etc.) which are categorized as CROP-signs (see Fig. 6). Since in these examples, the same semasiograms get preceded by different number of strokes in different inscriptions, such inscriptional patterns strongly indicate that these stroke-numerals were used for signifying some standardized quantification values. But, since only a fixed set of numerical signs get used, they could not have recorded the random quantities involved in everyday commercial transactions, as that would have required a more elaborate numerical system. Moreover, analysing the life-cycle of the inscribed seals and tablets of IVC, it becomes evident that they were engraved with inscriptions in highly regulated workshops (Kenoyer, 2005), long before they got circulated in different Indus locations. So, these inscriptions could in no way be used for recording different quantitative values involved in specific market transactions. They evidently recorded certain rules which needed to be followed in the commercial activities of IVC. So, considering that the semantic scope of Indus-Inscriptions was related to taxation and trade 
control, and the NUM-signs were used in a fixed pattern before specific semasiograms, this study confidently claims that the NUM-signs in these contexts meant certain fractions (or multiples of mensural units) that signified fixed tax-rates specified for certain commoditytypes. Those commodity-types, along with their commodity-specific metrological standards, were possibly expressed through the semasiograms following the numerical signs (e.g. $\Varangle$, $Y, Y, Y$, abundantly in ancient Mesopotamian and Greek bookkeeping (Nissen et al., 1993; Bennett, 1950: 204-222). When the PF1 signs get preceded by such numerals (Fig. 13c) those numerals possibly signified certain tax-rates used for paying the taxes through the specified metrological tax-category. This pattern, that only a limited range of numerical signs got used in Indus-Inscriptions, is explained by the fact that tax-rates are generally expressible through a very small set of numerals. For example, the rates of the newly imposed GST taxes of Indian government (since 2017 AD) largely involves only 4 slabs of $5 \%, 12 \%, 18 \%$ and $28 \%$ tax-rates, and hence are mostly expressible by just 4 fractional values. This claim also explains why certain numerals get used much more frequently than others in the inscriptions. In every complex economy (ancient or modern), it is generally the case that certain tax-rates are applicable to a large number of goods, whereas some others taxes are applicable to only a selected class of commodities. For example, while a large number of products and services fall under the 5\% GST category in modern India, gold and other precious stones was taxed with a special $3 \%$ rate in 2017 and a special $0.25 \%$ rate in 2018 . Similarly certain commodities in IVC might have been taxed with a more common rate, making certain numerical signs abundantly used in inscriptions, whereas certain commodities got taxed using a less frequent rate, and hence the semasiograms expressing them were qualified by a more restricted set of numerals.

\subsection{1-C Pattern-3: Phytomorphic signs signified grains, grain-based taxes, and standard grain measures}

Here I shall argue that the CROP-signs $\Psi, Y, Y$, etc., which resemble the ear or grainbearing tip part of the stem of a cereal plant, and occur frequently at the terminal positions of Indus inscriptions preceded by the numerical (fractional) signs for tax-rates (see Fig. 14d), possibly signified grains, standard grain measures, and related taxes. Sheaf-like graphemes were universally used as logograms of grain crops (see Fig. 14 a-c). In Mesopotamian art, a trident-like plant symbol was used (Miller, Jones \&Pittman, 2017) which closely resembles Indus CROP-sign $\Psi$. The proto-cuneiform ideograms for barley and wheat were also sheaflike signs (Fig. 14 a-b) (Miller, Jones \&Pittman, 2017; Nissen, Damerow \& Englund, 1993), whose graphical similarity with Indus CROP-signs was pointed out by Mahadevan (2006) as well. In Linear A and Linear B, phytomorphic signs were used to represent different grains and plants (e.g. olive), and they co-occurred with numerical signs to possibly represent different denominations (fractions or multiples) of standard grain measures in Linear A administrative tablets, such as 'one-eighth of the grain measure' (Corazza et al., 2021). As discussed by Corazza et al. (2021), "[m]easures were implicit in Linear A commodity logograms, and 
some of them were ligatured with fractional signs". Interestingly, Indus signs $\|$ and comparable ligatures combining the numerical sign \|\|$_{\text {, and the CROP-signs }} \Psi$ and

Figure-13 Numerical signs occurring in fixed patterns before specific semasiograms in Indus inscriptions

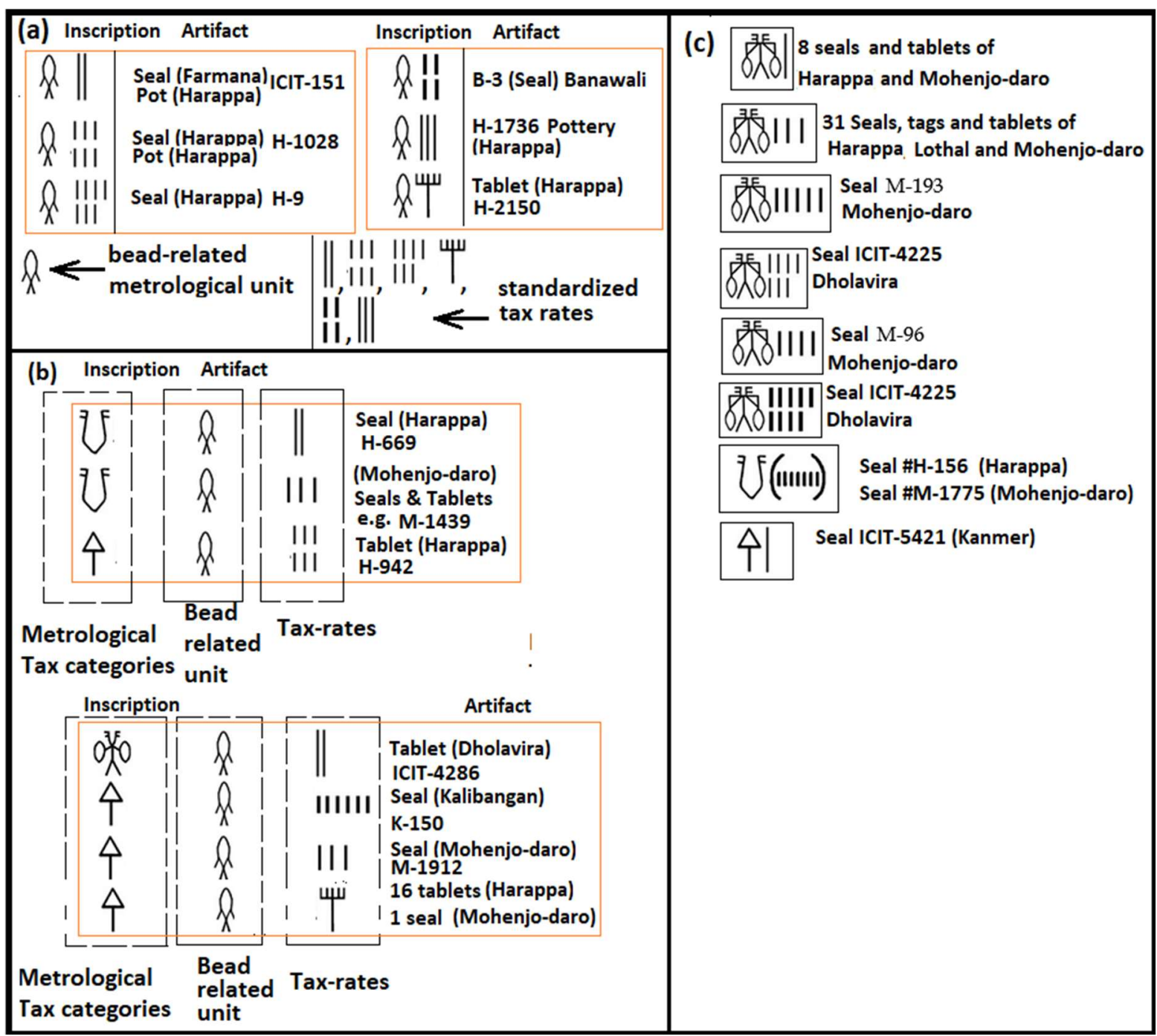

We get ample evidence of such implicit measures represented through commodity-specific logograms in Mesopotamian administrative tablets (Nissen et al., 1993). Since in ancient moneyless societies, the harvested crops were one of the most important sources and modes of revenue collection, they are expected to be frequently present in tax-related 
documents. This possibly explains why the phytomorphic CROP signs occurred in so many Indus-Inscriptions preceded by various numerical and metrological signs. I strongly suggest that in IVC the taxes imposed on harvested grains, or the taxes which were paid through harvested grains, were also named after those grains. In ancient India, such tax names were quite abundant. For example, the Sanskrit noun "dhānya", meaning paddy, also meant "produce of the fields, a share of which was payable to the king or landlord" (Sircar, 1966:91). Moreover, the Sanskrit term "dhānya-varga" literally meant "the grain group", actually meaning "class of taxes payable in grains", which is comparable to the Tamil taxation-terms "puravu-nēl", "nēl-ayam" etc. (Sircar, 1966:91,422). In IVC, such harvestbased taxes named after the common crops, such as barley, wheat etc. must have existed, and the crop-like signs arguably represented some of them, and their corresponding standard grain measures.

Figure 14 Symbols for grains, plants, and grain measures in ancient writing systems and their comparison with certain phytomorphic signs used in Indus inscriptions.

a) Proto-cuneiform barley sign b) Symbols and signs for grains and plants in Mesopotamian art and writing c) Phytomorphic Linear A and Linear B signs signifying grains, agricultural products and their standard measures d) Phytomorphic Indus signs occurring after numerical signs in Indus inscriptions e) Usage patterns of sign $\square$ that mostly occurs before phytomorphic signs. 


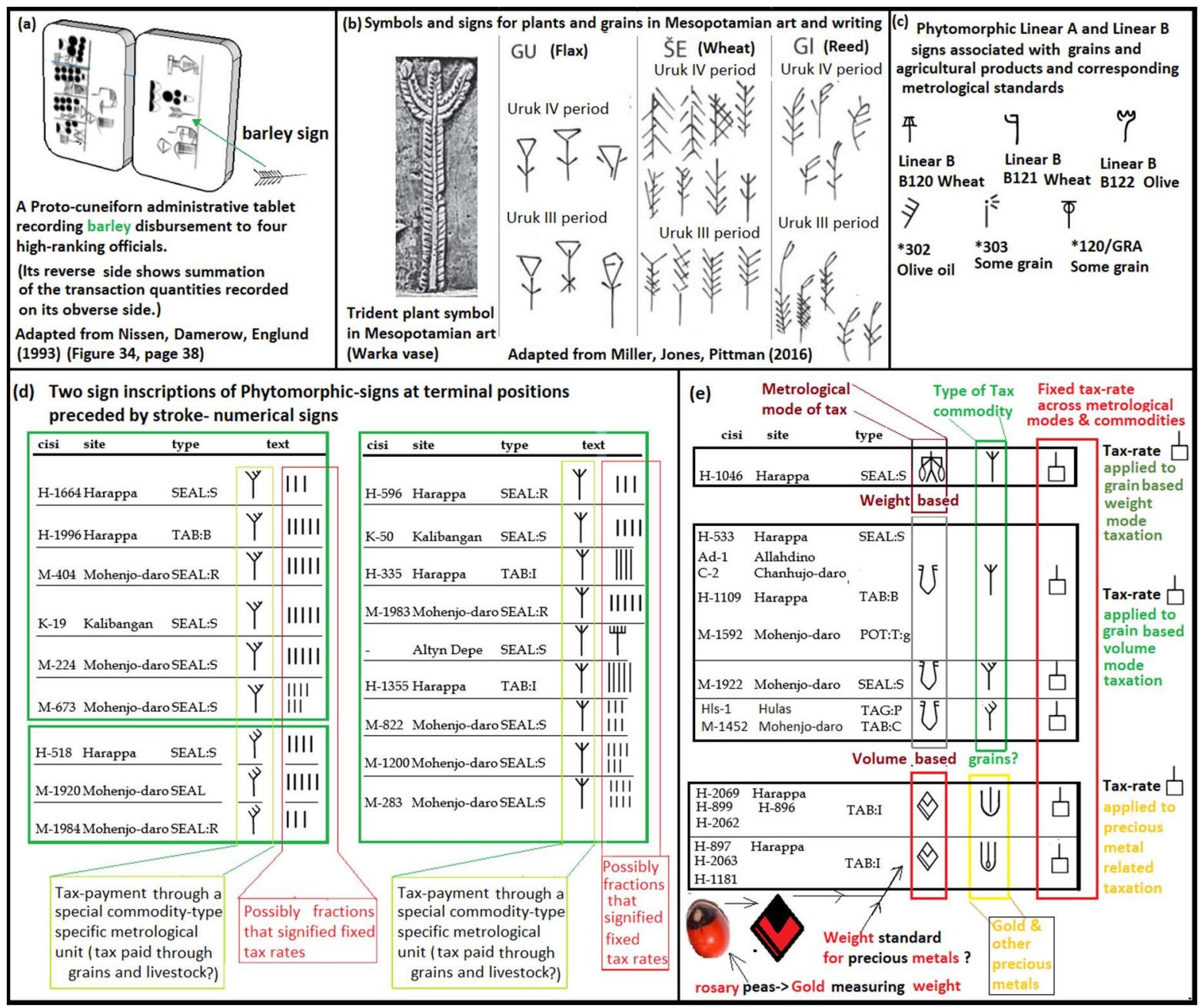

\subsection{1-D Sign $\square$ possibly signified a fixed tax-rate used across commodity-types}

Sign $\square$ occurs in around 224 inscriptions of ICIT, among which in around 55\% inscriptions it occurs preceding the CROP-signs. Interestingly, whenever preceded by $\square$, the crop signs never occur independently at the terminal positions of inscriptions, and they usually get followed by the PF1 signs that signify weight and volume-based taxation categories (see Fig. 14e). Thus, sign $\square$ replaces the numerical tax-rate signs preceding the CROP-signs and in doing so it needs the help of the signifiers of metrological-tax categories ( $\$ \wedge$ and $)$. Thus sign $\square$ possibly signified a special tax-rate, that remains fixed irrespective of the metrological modes of taxation. This conjecture gets further corroboration from the inscriptions $\hat{\nabla}$ blowpipe signs follow $\square$, in the same pattern as the crop signs, proving the applicability of 
in precious-metal related taxation. The next section shows how these inscriptions help in the identification of the semasiograms<smiles>C1=CC(C2C=C2)=CC1</smiles><smiles>[C]1C=CC=C1</smiles>
which were related to abrus precatorious seeds, the traditional Indian weighing standard for gold, and other precious metals, and the very basis of ancient Indian numismatics.

\subsection{1-E Identification of the Abrus precatorious (raktikā) seed-based signs $\mathbb{V}, \vec{V}$, and $\vartheta$, signifying goldsmith's weight standards, and related taxation systems}

Comparing the above-mentioned gold-based inscriptions

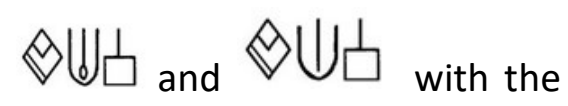
grain-based inscriptions $\{F \square$ and $8 \mathrm{~K} Y \square$, we clearly see that when the grain-based commodity-types ( $Y$ and $Y$, get replaced by precious-metal sign $\left(\int\right)$, then the volumebased and weight-based metrological modes of taxation ( 3 and $\mathrm{AS}$ ) also get replaced

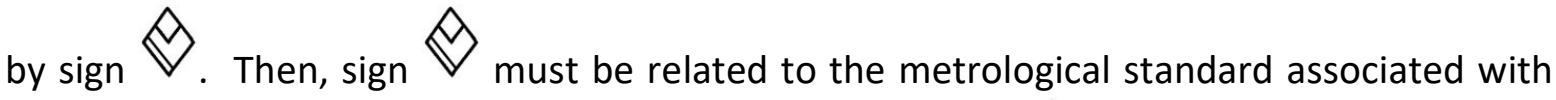
precious metals. We have already seen that the arrow-sign 1 is one such symbol related to gold-smith's balance and precious commodity taxation. Then should be another such metrological standard prevalent in IVC.

It is common knowledge that the abrus precatorious seeds were traditionally used as the basis of the gold-smith's weight in India (see references below). Intriguingly, sign uses a modified grapheme that is based on the graphemes of the frequent signs and , which as shown in Fig. 15c, have an unmistakable similarity with the abrus precatorious seeds. (As shown in Fig. 15a, sign $\checkmark$ is an allograph of sign and occur in identical pre-connective inscriptional contexts in several inscriptions). 


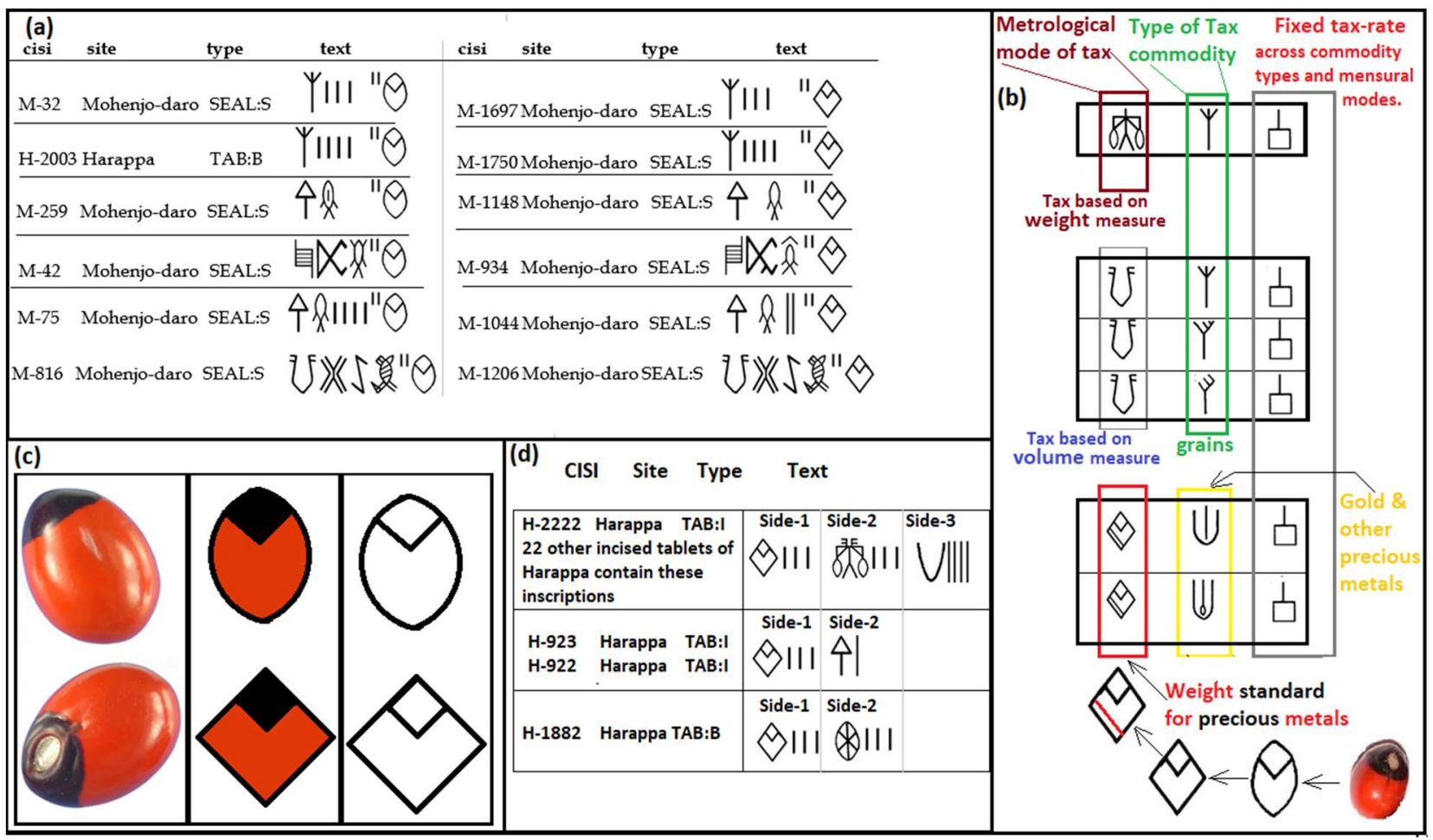

As described in Arthaśāstra (composed in Mauryan era, around 400 BC.), the seeds of abrus precatorious, also known as raktikā, kṛṣnala or guñjā seeds, were used as the basis of the weight system prevalent in ancient India. According to Kosambi (1975:174), 95\% of the 1059 punch-marked coins found in Taxila hoard, minted under Magadhan influence, "fall into the same range of variation in weight as do the accurately cut and very well-preserved ' $D$ ' class stone weights found in the Indus city excavations. The standard accords very well with the 32-raktika weight of the traditional karsapana". Intriguingly, in Taittiria Saṃhitā, Kāṭhaka Saṃhitā and other Vedic texts (c. 1200 B.C. to 1000 B.C.) kṛṣnala seeds are mentioned as units of gold measurement (Kosambi, 1975:121; Macdonell and Keith, 1912a:185; Bhandarkar, 1921:60). As explained by Bhandarkar, in Taittirīya-Brahmana, the passage "kṛṣnalam kṛ̣ṇalam vājașṛdbhyah prayacchati", which means "he gives a kṛ̣ṇala to each racer", shows beyond doubt the use of the name of "krșnala" seed as a particular gold coin (Bhandarkar, 1921:60). Thus, the continuity of the metrological systems of Mauryan period could be traced back to the Vedic period and even to the IVC era. The fact that even after the official adoption of metric system in 1956 in India, "ratti" (the measure based on raktikā seeds) is used to weigh gold and other gem stones in many urban and rural locations till date, proves how certain metrological standards prevalent in IVC have defied change for almost four millennia.

Intriguingly, many of the coinage standards used in ancient India in various times were not only based on the weight of "guñjā" seeds, but were also named based on the names of these seeds. Similarly, the "kākaṇa" or "kākiṇi" coins, which were so well known in ancient India, also were based on names of "Abrus precatorius", as the plant or its seeds too were called "kāka", "kākiṇī", "kākanantī" and "kākaṇantikā" (Monier-Williams, 1872). Just like "raktikā" or "ratti", the terms "kākiṇi", "kākaṇika" and "kāka" were also widely used as weight standards in ancient India for thousands of years, especially related to the coinage 
standards or money (Bhandarkar, 1921; Monier-Williams, 1872). Interestingly, in Telugu language a common word used for Abrus Precatorious is gurigiñja (Brown, 1903), which is evidently etymologically related to the word "guñja" present in Sanskrit, and it is difficult to say whether the words had ancient Proto-Dravidian or Old Indo-Aryan etymology. However, since the Telugu word "gimzza" or "ginza" means seed or grain in general (Brown, 1903), a more ancient non-Indo-Aryan etymology might have been more plausible in this case. In Tamil, a common word/root used for Abrus precatorious seeds is "kunni" (Tamil lexicon, 1924-36). Interestingly the "cinna" coins (Telugu "sinna") which were Canteroy fanams, a popular coin-system in South-India, Mysore, were based on the standard weight of gurigiñja seeds, whereas the Tamil weights "mañjāḍi" and "kalañju" were based on "kunnri-mani", and were used to weigh gold (Sircar, 1966). In fact, another Tamil word used for guri-ginja is gundu-mani, whereas gunḍu in Telugu means "a weight (stone) for scales" (Brown, 1903). Similarly, kalañju was also a Tamil name of a gold coin of 32 rati or guñja weight.

Now, since "guñjā" seeds have played such an important role in the weight and coinage systems across the northern and southern parts of ancient India (especially as the main unit for measuring precious stones and gold), and since they were the basis of the IVC weight system, the use of the guñjā-seed based sign $\vartheta$ in the context of gold/precious metal-based taxation and metrology, should not surprise us at all.

That the sign

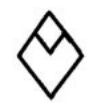
was related to metrological modes is also proven by the inscriptions listed in Fig. 15d. Here, 23 identical tablets found from Harappa have 3 inscribed sides each. In two of the sides metrological terminal signs $\bigcup$ and $8 / 8$ occur preceded by numerical signs. In the third-side $\widehat{\nabla}$ preceded by || $\mid$ occur, evidently as another metrological mode. These tablets possibly expressed certain tax-rate equivalencies to be maintained while taxing commodities of different types. Another revealing inscription comes from tablets H-922 and H-923 of Harappa. Here, the assay-balance related arrow-sign $\triangle$ used for precious metal taxation, and the guñjā-sign comes in two sides of these tablets. The arrow-sign $\widehat{T}$ is preceded by a single-stroke and the guñjā-sign is preceded by $1 \mid$ , evidently expressing the tax-rate equivalencies used for two prevalent metrological modes used for precious commodities. The pre-connective usage of the related signs

and<smiles>C1CCC2CCCC2C1</smiles>
are explained in Section 3.4.2.

\subsection{1-F Pattern-4: Numerical and metrological signs in pottery vessels signify capacity of the vessel or quantity of its content}


The numerical signs present in pottery vessels apparently had a different usage than expressing tax-rates. Many of the Indus pottery vessels were made of certain standard sizes, and the numeral signs present alone in their rim or body, quite obviously expressed the capacity of those vessels, or the quantity of their contents. Arthaśāstra has often mentioned use of various certified containers, measuring different denominations of the prevalent metrological standards, such as "kudava " or "prastha", which were used for commodity disbursement (Rangarajan, 1992).

\subsection{1-G Pattern-5: The pre-phrase-final signs possibly denoted the commodity-type used for paying tax (e.g. through grains, livestock, precious metals, and bead-based currency):}

As discussed in Section-3.1, the main characteristics of the pre-phrase-final/PPF signs are their inexorable tendency of occurring immediately before the PF1s (see AnsumaliMukhopadhyay, 2019 for details). Now, since the PF1-signs represented the metrological modes of revenue collection, and in turn possibly metonymically represented the names of the associated revenue categories, the PPF-signs closely attached to the PF1-signs are hypothesised to mean the commodity used as the mode of the revenue payment.

An important reason behind this hypothesis is the shared iconicity between the PF1signs and PPF-signs. The grapheme of the most frequent PPF-sign $Y^{Y}$ is formed by combining

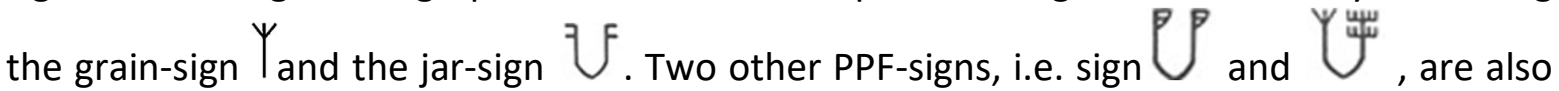
created using the grapheme of jar-sign $\mathcal{V}$. Considering the iconicity of the signs deciphered in Section-3.2, we can be now sure that the semantic-scope of Indus semasiograms are closely related to the symbols chosen for their graphemes. Thus, since the PPF and PF1 signs not only sit adjacently, but also share similar graphemes, they must be semantically related. In inscription $[E \mathcal{E}$. to form sign $Y$, which further demonstrates the semantic association between the PPF and PF1-signs that could lead to such ligatures. A very strong proof of the PF1-PPF relationship comes from the great affinity between the PF1 sign ${ }^{-}$(allographs 目, and ), and the pincer/tong like signs $\underbrace{}_{\text {, and }}$, as whenever sign 目 $_{\text {occurs at the }}$ terminal positions of inscriptions, the pincer-like signs occur preceding sign 自 in around $80 \%$ cases.

Now, the use of a grain-based sign $\Psi$ in the grapheme of the PPF-sign $\mathcal{Y}^{\prime}$, is symbolically quite significant, as in barter-based economies, harvested grains were one of the main ways to pay revenue. Some relevant revenue terminologies prevalent in ancient India are (Sircar, 1966): 
i) "tāniya-varakkam" (Tamil) or "dhānya-varga" (Sanskrit): "the grain group" i.e. "class of taxes payable in grains";

ii) 'alpam-irai' (Sanskrit-Tamil): "a minor tax payable in grains"

iii) "dhānyāya" (Sanskrit) and "nēl-āyam" (Tamil-Sanskrit): "tax in grains"

iv) "puravu-nēl" (Tamil): "revenue paid in paddy"

v) "āl- nēl": "tax payable in paddy"

Thus, since the most frequent PPF-sign $\mathcal{Y}^{\Psi}$ is graphically constituted of the most frequent CROP-sign $\Psi$ arranged in a jar-like shape, this study proposes that $\Psi_{\text {possibly symbolized }}$ a standardized vessel full of grains, and signified the taxes paid through grains as a mode.

In contrast to the taxes payable in grain, there were various types and classes of taxes that were payable through gold or coins in ancient historical India. Some such relevant terms are (Sircar, 1966): "hiraṇya-āya" (Sanskrit), "hiraṇya-deya" (Sanskrit), "paṇa-vargam" (Tamil/Sanskrit), "kāśu-āyam" (Tamil-Sanskrit), "kāśu-vargam" (Tamil-Sanskrit), "kāśukaḍamai" (Tamil), "ponvari” (Tamil), "pon-vargam" (Tamil-Sanskrit), "swarṇa-vari" (SanskritTamil) etc.

Now, in IVC, though the abstract concept of money was not present, there must have been taxation equivalencies for taxes paid through different kinds, such as precious stone beads, precious metals such as gold, silver, copper, clothes etc., and other such commodities. Thus Indus tax-stamps had to record such modes of taxation, whenever needed. Possibly that is the reason of having

Similarly, though the PF1-sign 目 cannot be yet interpreted, its association with the pincer/tong-like signs ( of metal-smithy. Thus it is possible that in the inscriptions containing such combinations (see Fig. 16), the mode of tax-payment was through certain metal ores or implements.

\section{A brief discussion of the iconographies present in the seals and tablets:}

Though I have limited the focus of this study mainly to the inscriptions, not the iconography present on the inscribed objects, iconographies too played a vital part in the information content of these "formalized data carriers". Unlike many scholars, who have proposed that the seal/tablet inscriptions contained the names of the seals' owners or issuers, this study argues that the inscriptions mostly contained information about taxed commodities, taxpayment modes, tax-categories, and tax-receiving entities. But, there must have been a way 
to identify the issuing authorities of these seals and tablets, in order to establish their authority in the contexts of related transactions. This study argues that the iconographies were actually used for this purpose. Most of the Indus iconographies are animal-centric, depicting bulls, unicorns, tigers, elephants, crocodiles, and various anthropomorphic figures. Interestingly, certain ancient Indian tribes were actually named after animals. For example, the Vedic texts refer to tribes or people called, "Mahavrșa" (big bull), "Aja" (goat), "Matsya" (fish) etc. (Macdonell and Keith, 1912 a,b). Thus, these animal-centric Indus iconographies arguably denoted the "guilds" or oligarchic authorities that issued the inscribed seals and tablets. Since the iconographic symbols such as the "unicorn" were found in different stratigraphic layers of Indus locations (spanning over a long time period), and in far-flung Indus locations, it could not have signified a single king, chieftain, or a single royal family. Moreover, the existence of several seal-impressions on single sealings, sometimes having different iconographies for each seal (Sealing \#1625 has 3 seal impressions with separate iconographies of bull, unicorn and tiger), proves that the issuing authorities of each seal had some agreement with one another, and hence the issuing authorities are more likely to be symbiotic "merchant guilds" rather than competing royal families. This forms the basis of my hypothesis that the iconographies represented guilds or oligarchic authorities. Another strong corroborative support of this theory comes from the punch-marked coins of prehistoric and early-historic era, where animals like "lion", "tiger", "elephant", "bull", "boar", "peacock", etc., functioned as insignias of different clans and dynasties. Possibly the troughlike or manger-like symbols placed before such animals represented the act of "feeding" such guilds, i.e. paying them revenue.

\section{Supplementary information}

Supplementary-File-1: An image of a news in an online Bengali News Daily (https://www.banglanews24.com/economics-business/news/bd/729151.details) to show the use of the ancient word "don" as a metrological noun.

\section{References}

Ahmed M. Ancient Pakistan - An archaeological history: volume IV: Harappan civilization theoretical and the abstract. Reidsville NC: Foursome Group, 2014.

Allchin B, Allchin R. The rise of civilization in India and Pakistan. Cambridge: Cambridge University Press; 1982.

Allen, J. P. (2000). Middle Egyptian: An introduction to the language and culture of hieroglyphs. Cambridge University Press. 
Azarpay G. Sogdian painting: the pictorial epic in oriental art. Berkeley: University of California Press; 1981.

Belcher WR. Fish exploitation of the Baluchistan and Indus valley traditions: An ethnoarchaeological approach to the study of fish remains. 1998; Doctoral dissertation, University of Wisconsin-Madison.

Bhan, KK. Review of prehistoric cultures of Gujarat and need to develop accurate settlement gazetteer. International Symposium in India on Changing Perceptions of Japan in South Asia in the New Asian Era: The State of Japanese Studies in India and Other SAARC Countries. Kyoto, Japan: International Research Center for Japanese Studies; 2011.

Bhandarkar DR. Lectures on ancient Indian numismatics. Calcutta: University of Calcutta; 1921. Available from: https://archive.org

Bloomfield, M. (1899). Atharvaveda. KJ Trübner.

Bonta Steven. The Indus valley script: A new interpretation (A Semiologic approach showing distributional evidence and markedness as tools for interpreting patterned texts in the Harrapan corpus.). Penn. State University - Altoona College; 2010

Brown, C P (1903). A Telugu-English dictionary (Vol. 2). Society for Promoting Christian Knowledge. Available at https://dsalsrv04.uchicago.edu/dictionaries/brown/

Budge EW. An Egyptian hieroglyphic dictionary: with an index of English words, king list, and geographical list with indexes, list of hieroglyphic characters, Coptic and Semitic alphabets, etc. London : John Murray, London; 1920. Available from: https://archive.org

Bühler G. On the origin of the Indian Brahma alphabet. Strassburg: K.J. Trübner; 1898. Available from: https://archive.org

Cameron GG. Persepolis treasury tablets. Chicago: University of Chicago Press; 1948. Available from: https://oi.uchicago.edu

Carey WA. dictionary of the Bengali language, Bengali-English. New Delhi: Asian Educational Services; 1981.

Chadwick J. The decipherment of Linear B. 2nd ed. Cambridge: Cambridge University Press; 1990.

Clegg J. The medieval church in manuscripts. Toronto, Buffalo: University of Toronto Press; 2003.

Clough B. A Sinhalese-English dictionary. Colombo: Wesleyan Mission Press; 1892.

Cruse D A (1986) Lexical semantics. Cambridge University Press: Cambridge.

In Kenoyer, J. M. (2017). Walking with the Unicorn. 
Donkin RA. Beyond price: pearls and pearl-fishing: Origins to the age of discoveries. Philadelphia: American Philosophical Society; 1998.

Drekmeier C. Kingship and community in early India. Stanford: Stanford University Press; 1962.

Elliott JH. Beware the evil eye: The evil eye in the Bible and the ancient world. Vol. IV: Postbiblical Israel and early Christianity through late antiquity. Eugene, Oregon: Cascade Books; 2017.

Farmer S, Sproat R, Witzel M. The collapse of the Indus-script thesis: The myth of a literate Harappan civilization. Electronic Journal of Vedic Studies (EJVS). 2004; 11(2):19-57.

Flood GD. An introduction to Hinduism. Cambridge: Cambridge University Press; 1996.

Francis P.Jr. Asia's maritime bead trade: 300 BC to the present. Honolulu: University of Hawaii Press; 2002.

Frankel E, Teutsch BP. The encyclopedia of Jewish symbols. Northvale, NJ: Jason Aronson; 1992.

Frenez D (2017) Private Person or Public Persona? Use and Significance of Standard Indus Seals as Markers of Formal Socio-Economic Identities. In: Kenoyer, J. M. (2017). Walking with the Unicorn.

García JC., editor. Ancient Egyptian administration. Leiden; Boston: Brill; 2013.

Gardiner SA. Egyptian grammar: Being an introduction to the study of hieroglyphs. 3rd revised ed. Published on behalf of the Griffith Institute, Ashmolean Museum. Oxford University Press; 1969.

Gelb IJ. Makkan and Meluhb̧a in early Mesopotamian sources. Revue d'Assyriologie et d'archéologie orientale. 1970 Jan 1; 64(1):1-8.

Ghosh S (2005, January). MONETIZATION AND EXCHANGE NETWORK IN EARLY HISTORIC BENGAL: A NOTE DEFINING CERTAIN PROBLEMS. In Proceedings of the Indian History Congress (Vol. 66, pp. 110119). Indian History Congress.

Halloran JA. Sumerian lexicon: A dictionary guide to the ancient Sumerian language. Los Angeles: Logogram Publishing; 2006.

Harlan JR. The living fields: our agricultural heritage. Cambridge; New York: Cambridge University Press; 1998.

Howard-Carter T. Eye-Stones and pearls. In: Khalifa SH., Rice M., editors. Bahrain through the ages: The archaeology. London and New York: Routledge: 1986. p. 305-10.

Jarrige JF. Mehrgarh neolithic. Pragdhara. 2008;18:136-54. Available from: http://archaeology.up.nic.in/doc/mn_jfj.pdf

Johns $\mathrm{CH}$. Babylonian and Assyrian laws, contracts, and letters. Union, NJ: The Lawbook Exchange, Ltd.; 1999.

Joshi JP, Parpola A. Corpus of Indus seals and inscriptions. I. Collections in India. In: Annales Academiae Scientiarum Fennicae. Series B 1987. Vol. 239. Helsinki: Suomalainen Tiedeakatemia; 1375. 
Kenoyer JM. Ancient cities of the Indus valley civilization. American Institute of Pakistan Studies. Karachi: Oxford University Press; 1998.

Kenoyer JM. Early developments of art, symbol and technology in the Indus Valley tradition. IndoKoko-Kenkyu, Indian Archaeological Studies. 2001; 22:1-18.

Kenoyer JM. Eye beads from the Indus Tradition: Technology, style and chronology. Journal of Asian Civilizations. 2013; Dec 1;36(2):1.

Kenoyer JM. Measuring the Harappan world: insights into the Indus order and cosmology. In: Morley lain, Renfrew Colin, editors. The archaeology of measurement: comprehending heaven, earth and time in ancient societies. Cambridge; New York: Cambridge University Press; 2010. p. 106-122.

Kenoyer JM. The origin, context and function of the Indus script: Recent insights from Harappa. In: Osada T, Hase N, editors. Proceedings of the pre-symposium and the 7th ESCA Harvard-Kyoto Roundtable. Kyoto: Research Institute for Humanity and Nature; 2006:9-27.

Kittel F. A Kannada-English dictionary. 1st ed. Mangalore: Basel Mission Book and Tract Depository; 1894. Available from: https://archive.org.

Kosambi DD. An introduction to the study of Indian history. Bombay: Popular Prakashan; 1975.

Kosambi DD. Indian numismatics. New Delhi: Orient Longman; 1981. Available from: https://archive.org

Kuhrt A. The ancient Near East, c. 3000-330 BC. London and New York: Routledge; 1995.

Kula W. Measures and men. Princeton, NJ: Princeton University Press; 2014.

Macdonell AA, Keith AB. Vedic index of names and subjects.Vol. I London : John Murray, London; 1912a. Available from: https://archive.org

Macdonell AA, Keith AB. Vedic index of names and subjects.Vol. II Reprint. London : John Murray; London; 1912b. Available from: https://archive.org

MacEachern M R (1999) Laryngeal Cooccurrence Restrictions. Garland Publishing: New York \& London.

Mahadevan I. Agricultural terms in the Indus script. Journal of Tamil Studies. 2006; Dec;70(1):64-76.

Mahadevan I. Akam and puram: 'Address' signs of the Indus script. International Journal of Dravidian Linguistics. 2011;40(1);81-94.

Mahadevan I. Dravidian proof of the Indus script via the RigVeda: A case study. Bulletin of the Indus Research Center. Chennai: Roja Muthiah Research Library. 2014 Nov(4);37.

Mahadevan I. The Indus script: texts, concordance, and tables. Calcutta; Delhi: Archaeological Survey of India; 1977.

Mahadevan I. Towards a grammar of the Indus texts: Intelligible to the eye, if not to the ears. Tamil Civilization.1986; 4(3-4):15-30. 
Marshall, J. (Ed.). (1931). Mohenjo-Daro and the Indus civilization: being an official account of archaeological excavations at Mohenjo-Daro carried out by the Government of India between the years 1922 and 1927 (Vol. 1). Asian Educational Services.

McIntosh J. The ancient Indus valley: new perspectives. Santa Barbara, Calif.: Abc-Clio; 2008.

McKoy B (2009). The Wings of Isis. John Hunt Publishing.

Monier-Williams M. A Sanskrit-English Dictionary Etymologically and Philologically Arranged: With Special Reference to Greek, Latin, Gothic, German, Anglo-Saxon, and Other Cognate Indo-European Languages. Clarendon Press; 1872. Available from: http://www.sanskrit-lexicon.unikoeln.de/scans/MW72Scan/2014/web/webtc2/index.php

Moorey PR. Ancient Mesopotamian materials and industries: the archaeological evidence. Winona Lake, Ind.: Eisenbrauns; 1999.

Mukhopadhyay B A (2019). Interrogating Indus inscriptions to unravel their mechanisms of meaning conveyance. Palgrave Communications, 5(1), 73.

Narain AK. Ganesa: a protohistory of the idea and the icon. In: Brown RL, editor. Ganesh: studies of an Asian god. Albany: SUNY Press; 1991

Nissen HJ., Damerow P, Englund RK. Archaic bookkeeping: early writing and techniques of economic administration in the ancient Near East. Trans Larsen P. Chicago, III.; London: University of Chicago Press; 1993.

Pal P, Richardson H. Art of Tibet: a catalogue of the Los Angeles county museum of art collection. Los Angeles, Calif.: The Museum; Berkeley: in association with University of California Press, 1983.

Parpola A, Pande BM, Koskikallio P, editors. Corpus of Indus seals and inscriptions: Mohenjo-daro and Harappa. 3: New material, untraced objects, and collections outside India and Pakistan. Helsinki: Suomalainen Tiedeakatemia; 2010.

Parpola A. Deciphering the Indus script. Cambridge: Cambridge University Press; 1994.

Parpola A. The roots of Hinduism: the early Aryans and the Indus civilization. New York: Oxford University Press; USA; 2015.

Parpola S, editor. Assyrian-English-Assyrian dictionary. Helsinki Winona Lake, Ind.: Neo-Assyrian Text Corpus Project; 2007.

Pitts-Taylor V., editor. Cultural encyclopedia of the body. [2 volumes]. Westport, Conn.; London: Greenwood Press; 2008.

Possehl GL. The Indus civilization: a contemporary perspective. Walnut Creek, CA: AltaMira Press; 2002.

Powell, Marvin A. 1990. Masse und Gewichte. In: Reallexikon der Assyriologie, Siebenter Band. Berlin - New York: de Gruyter 1987-1990, 457-516. 
Prasad KD. Taxation in ancient India: From the earliest times up to the Guptas. Delhi: Mittal Publications; 1987.

Pruthi RK. The classical age. New Delhi: Discovery Publishing House; 2004.

Rainey AF. The El-Amarna correspondence: A new edition of the cuneiform letters from the site of El-Amarna based on collations of all extant tablets. Leiden: Brill; 2014.

Ranade MG. Rise of the Maratha power. Bombay: Punalekar \& Company; 1900.

Rangarajan LN., editor. The Arthashastra. Delhi: Penguin Books India; 1992.

Rao SR. The decipherment of the Indus script. Bombay: Asia publishing house; 1982.

Roth M. T., editor. The Assyrian dictionary. P. Volume 12. Chicago: University of Chicago; 2005.

Reiner E., editor. The Assyrian dictionary: Š Volume 17. Part-iii. Chicago: University of Chicago; 1992.

Reiner E., editor. The Assyrian Dictionary: Volume 15-S. Chicago: University of Chicago; 1984.

Reis L C \& Hibbeln J R (2006) Cultural symbolism of fish and the psychotropic properties of omega-3 fatty acids. Prostaglandins, Leukotrienes and Essential Fatty Acids, 75(4-5), 227-236.

Rogers RW, editor. Cuneiform parallels to the Old Testament. New York: Eaton \& Mains; 1912.

Rowe BM, Levine DP. A concise introduction to linguistics. 4th ed. London, New York: Routledge; 2016.

Sarkar KR. Public finance in ancient India. New Delhi: Abhinav Publications; 2003.

Sarma B. Vyasa's Mahabharatam. Kolkata: Academic Publishers; 2008.

Scurlock J. Sourcebook for ancient Mesopotamian medicine. Atlanta, Georgia: SBL Press; 2014.

Shah SG, Parpola A. Corpus of Indus seals and inscriptions. 2. Collections in Pakistan. In: Annales Academiae Scientiarum Fennicae. Series B 1991 (Vol. 240). Helsinki: Suomalainen Tiedeakatemia.

Shamasastry R. Kautilya's Arthaśāstra. Mysore: Wesleyan Mission Press; 1929. Available from: https://archive.org

Sharlach TM. Provincial taxation and the Ur III state. Boston: Brill; 2004.

Sircar DC. Indian epigraphical glossary. Delhi; Varanasi; Patna: Motilal Varanasi Dass; 1966.

Solé M J (1999) The phonetic basis of phonological structure: The role of aerodynamic factors. In: Proceedings of the Ist Congress of Experimental Phonetics: Tarragona, Spain, pp 77-94.

Tavernier J. Iranica in the Achaemenid period (ca. 550-330 BC): Lexicon of old Iranian proper names and loanwords, attested in non-Iranian texts. Leuven; Paris; Dudley, MA : Peeters; 2007. Available from: https://archive.org 
Taylor J. Lilawati: Or a treatise on arithmetic and geometry by Bhāskara Āchārya. Trans. Taylor John. Bombay: Courier Press; 1816.

Thapar R. The Penguin history of early India: from the origins to AD 1300. London: Penguin; 2015.

Turner RL. A comparative dictionary of the Indo-Aryan languages. Vol. I Delhi: Motilal Banarsidass Publisher; 1999.

University of Madras. Tamil lexicon. [Madras], University of Madras, 1924-1936. Available from: http://dsal.uchicago.edu/dictionaries/tamil-lex/

Vidale M. Growing in a Foreign World. For a history of the 'Meluhha Villages' in Mesopotamia in the 3rd Millennium BC. In: Melammu Symposia 4: Proceedings of the Fourth Annual Symposium of the Assyrian and Babylonian Intellectual Heritage Project. 2004. p. 261-280.

Wells BK, Andreas F. The archaeology and epigraphy of Indus writing. Oxford: Archaeopress; 2015.

Wells BK, Fuls A. Online Indus Writing Database. Berlin: 2006 Available from: http://caddy.igg.tuberlin.de/indus/welcome.htm. Accessed: May 1, 2016.

Wells BK. Epigraphic approaches to Indus writing. American School of Prehistoric Research Monograph. Oakville, CT: Oxbow Books; 2011.

Williams JH. Defining and measuring nature: The make of all things. San Rafael, CA: Morgan \& Claypool Publishers; 2014.

Witzel M. Aryan and non-Aryan Names in Vedic India. Data for the linguistic situation, c. 1900-500 B.C. In: Bronkhorst J, Deshpande M, editors. Aryans and Non-Non-Aryans, Evidence, Interpretation and Ideology. Cambridge: Harvard Oriental Series, Opera Minora 3. 1999. 337-404. Available from: https://www.people.fas.harvard.edu

Witzel M. The languages of Harappa: Early linguistic data and the Indus civilization. Electronic Journal of Vedic Studies 2000 Feb;6:1-44.

Woods C. Visible language: the earliest writing systems. In: Woods C. Editor. Visible language: Inventions of writing in the ancient middle east and beyond. Chicago: The Oriental Institute of the University of Chicago, Chicago. 2011. p. 15-25. Available from: https://oi.uchicago.edu/sites/oi.uchicago.edu/files/uploads/shared/docs/oimp32.pdf.

Wright R P, Lentz D L, Beaubien H F, \& Kimbrough C K (2012) New evidence for jute (Corchorus capsularis L.) in the Indus civilization. Archaeological and Anthropological Sciences, 4(2), 137-143.

Sign and image: representations of plants on the Warka Vase of early Mesopotamia. NF Miller, $\mathrm{P}$ Jones, H Pittman - Origini, 2017

Corazza, M., Ferrara, S., Montecchi, B., Tamburini, F. and Valério, M., 2021. The mathematical values of fraction signs in the Linear A script: A computational, statistical and typological approach. Journal of Archaeological Science, 125, p.105214. 
Bennett, Emmett L. "Fractional quantities in Minoan bookkeeping." American Journal of Archaeology 54.3 (1950): 204-222.

Mackay, Ernest. "Chanhu-Daro Excavations: 1935-36." American Oriental Series, New Haven, Connecticut (1943).

Mackay, Ernest John Henry. Further excavations at Mohenjo-daro. Vol. 2. Manager of publications, 1938

Montecchi, Barbara. "The Conceptualization of Measuring and Counting in the Bronze Age Aegean." Annali (Istituto Italiano di Numismatica) 63 (2017): 9-34 